\title{
Production and Selection of Metal PET Radioisotopes for Molecular Imaging
}

\author{
Suzanne V. Smith ${ }^{1,2}$, Marian Jones ${ }^{1}$ and Vanessa Holmes ${ }^{1}$ \\ ${ }^{1}$ Centres of Excellence in Antimatter Matter Studies (CAMS) at \\ Australian Nuclear Science and Technology Organisation, and \\ ${ }^{2}$ The Australian National University \\ Australia
}

\section{Introduction}

Today advances in the design of modern drugs rely on an understanding of their mechanism of action. Positron Emission Tomography (PET) has proven to be an important imaging tool for diagnosis in oncology, cardiology and neurology and more recently in personalised medicine (Roach, M. et al., 2011; Smith, S.V., 2005). Its exquisite sensitivity $\left(<10^{-9} \mathrm{M}\right)$ has made it a valuable tool in the screening and risk assessment of new agents in drug development programs (Cropley, V.L. et al., 2006; Gomes, C.M.F. et al., 2011; Gregoire, V. et al., 2007; Lancelot, S. \& Zimmer, L., 2010; Langer, A.2010; Lonsdale, M.N. \& Beyer, T., 2010; Roach, M. et al., 2011; Seam, P. et al., 2007; Truong, M.T. et al., 2011; Vyas, N.S. et al., 2011; Wahl, R.L. et al., 2009). It has been mainly focused on the use of the classical short lived PET isotopes, ${ }^{11} \mathrm{C}$ and ${ }^{18} \mathrm{~F}$, in the evaluation of small molecular weight molecules. PET contributions to the molecular imaging and drug development fields however would be significantly enhanced if longer lived PET radioisotopes were readily available. Generally metal PET radioisotopes are better suited for labelling larger molecular agents such as peptides, proteins and particles. This chapter will review a range of metal PET radioisotopes under development, assess their physical characteristics and suitability for PET imaging.

\subsection{How does PET work?}

The high sensitivity of PET is related to its mode of detection. The positron $\left(\beta^{+}\right)$which is emitted from the PET isotope must lose sufficient energy (to $<100 \mathrm{eV}$ ) so it is able to attach to an electron and form the neutral, unstable positronium. The positronium annihilates rapidly (within less than 150 picoseconds (ps)) to give off two $511 \mathrm{keV}$ gammas simultaneously, in opposite directions. If the two coincident gammas are detected by the circumferentially arranged detectors within a fixed time period, it is assumed that they arise from the same radioactive source (see Figure 1). This co-registration of the gamma signals allows one to determine the location and concentration of the PET probe in the body (Lonsdale, M.N. \&Beyer, 2010 T.; Smith, S.V., 2005).

\section{PET Imaging}

The quality of information gained by PET imaging is governed by the spatial resolution and sensitivity of PET to the radioisotope used. While the sensitivity and flexibility of PET is 
superior to other existing imaging modalities it lacks the anatomical or structural detail achieved with CT and MRI (Smith, S.V., 2007). Today PET technology has evolved significantly in design, detector type, data processing and construction of hybrid systems. This section will give an overview of this evolution and future opportunities for PET. Table 1 summarises the latest relative spatial resolution of human and animal cameras (Bockisch, A. et al., 2009; Cai, W.B. \&Chen, X.Y., 2008; Cañadas, M.E. et al., 2008; Kitajima, K. et al., 2011; Lewellen, T.K., 2008; Wang, C. et al., 2010). The reader is encouraged to consider a number of excellent reviews for more detailed discussion.

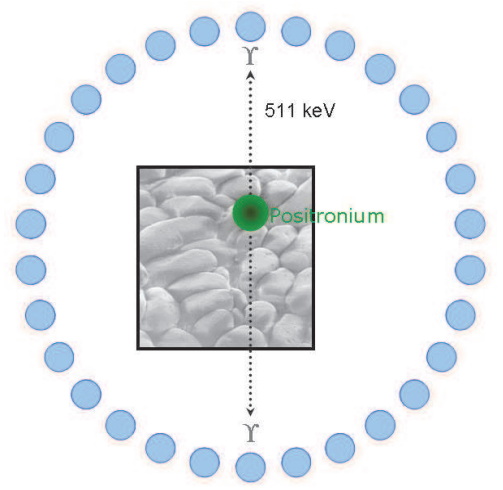

Fig. 1. Detection of coincident gamma rays from positronium annihilation

\begin{tabular}{|c|c|c|c|c|}
\hline \multicolumn{2}{|c|}{ Human } & \multicolumn{3}{c|}{ Animal } \\
\hline & $\begin{array}{c}\text { Resolution } \\
(\mathbf{m m})\end{array}$ & & Resolution & $\begin{array}{c}\text { Sensitivity } \\
\text { (moles detected) }\end{array}$ \\
\hline TOF-PETa $^{a}$ & $2-3$ & PET & $1-2 \mathrm{~mm}$ & $10^{-15}$ \\
\hline SPECTa $^{2}$ & $6-10$ & SPECT & $1-2 \mathrm{~mm}$ & $10^{-14}$ \\
\hline MRI $^{a}$ & $<1$ & MRI & $50 \mu \mathrm{m}$ & $10^{-9}$ to $10^{-6}$ \\
\hline CT $^{a}$ & $<1$ & CT & $50 \mu \mathrm{m}$ & $10^{-6}$ \\
\hline
\end{tabular}

a Time of Flight Positron Emission Tomography; Single Photo Emission Computed Tomography; Magnetic Resonance Imaging; Computed Tomography

Table 1. Comparison of specification of Human and Animal Cameras (Baker, M., 2010; Pimlott, S.L. \&Sutherland, A., 2011; Smith, S.V., 2005)

\subsection{Human PET cameras}

The first PET camera was developed in the 1950s and by the 90s they were well established imaging tools. Its detectors (up to 32 thousand) are arranged in a ring around the subject of interest. To obtain an image, the subject containing the PET agent is moved within the field of view of the detectors. The radioactivity present in the region of interest is measured and the data is processed to generate a $3 \mathrm{D}$ image. The radial distribution of the detectors can be varied. For human whole body and brain imaging PET diameters are approximately 70-87 $\mathrm{cm}$ and 40-50 cm, respectively (Lee , J.S., 2010; Moses, W.W. et al., 1997). The further the detectors are placed apart the more likely the gamma signal will deviate from $180^{\circ} \mathrm{C}$ (i.e. 
become non-collinear) compromising spatial resolution. As a result, whole body and brain PET have optimum resolutions of approximately $4-6 \mathrm{~mm}$ and $2 \mathrm{~mm}$ (Lancelot, S. \& Zimmer, L., 2010). For animal PET, the radial distance of the detector is smaller therefore the achievable spatial resolution is $1-2 \mathrm{~mm}$ (using ${ }^{18} \mathrm{~F}$ ). Because the detectors are closer, images can be significantly affected (i.e. become blurred) by high energy positrons and gammas (350 - 700 $\mathrm{keV})$. This comparatively poor spatial resolution of PET created the need to combine it with high resolution anatomical data obtained with CT and MRI. Initially this was achieved by fusion imaging, where images are taken from independent CT and PET cameras and merged to produce a single image.

By 1998 CT and PET detectors were integrated into a single system (Winant, C.D. et al., 2010). The separate images were superimposed and produced images of superior quality than their respective stand-alone systems. Today, stand alone PET systems comprise less than $10 \%$ of the PET market and their sales are projected to cease by 2015 (Frost \& Sullivan, 2010). There are almost 5000 PET-CT systems worldwide, while stand-alone PET tend to be purchased only when patient throughput is low or a diagnostic CT camera is in routine operation.

PET-CT is mostly used for oncology studies (95\%), however both neurology (3\%) and cardiology (2\%) are expected to grow to 15 and $10 \%$, respectively. Rubidium-82 is becoming the agent of choice for myocardial perfusion imaging (MPI). Generator produced ${ }^{82} \mathrm{Rb}$ can be made widely available. Compared to traditional SPECT agents, such as $99 \mathrm{mTc}$ (terefosmin) and ${ }^{201} \mathrm{Tl}$, it provides equivalent or better performance with 5-20 times lower radiation dose. The next generation of PET-CT scanners will have 64-slice CT scanners (64 slice) and are expected to improve their competitive edge (Winant, C.D. et al., 2010). In neurology, 18FDG has already proven its ability in differential diagnosis of dementias, such as Alzheimer's disease from frontotemporal dementia and normal patients. The recent launch of the clinical trial of the $18 \mathrm{~F}-\mathrm{PET}$ amyloid imaging agent $(18 \mathrm{~F}-\mathrm{AV}-45)$ is expected to further expand the role of PET-CT in neurology.

Even though the PET and CT images must still be acquired sequentially, the PET-CT systems have increased the patient throughput by $30 \%$, reducing time and cost to patient and healthcare providers. These systems have enhanced collaboration between the nuclear medicine and radiology communities, leading to improved quality of care to the patient and increased potential for reimbursements for the radiopharmaceuticals used.

More recently PET has been able to capitalise on Time of Flight (TOF) techniques to enhance image resolution. The first TOF-PET system was developed as far back as the 80s, but only in recent times have detectors and data processing capabilities been sufficiently costeffective to incorporate this capability into commercial systems (Lee, J.S., 2010). TOF-PET can be used to reduce scan time or quantity of radiotracer required to obtain the image (Moses, W.W., 2007). This advancement has been particularly important for larger patients $(>115 \mathrm{~kg}$ and $\mathrm{BMI} \geq 38)$ (Lee, J.S., 2010) where small lesion detection can be difficult. Further advances in the timing resolution to less than 500 picoseconds is expected to improve signal to noise ratio and image contrast. This will provide more accurate tracer quantification in small structures. One drawback for PET-CT is the radiation dose and poor soft tissue contrast. It has created the impetus for the development of MRI and PET hybrid systems (Wolf, W., 2011).

PET-MRI is emerging as a disruptive technology. (Lancelot, S. \& Zimmer, L., 2010). Still only used in research communities, the advancement of PET-MRI has relied on improved resolution and stability of solid state detectors for PET. These are smaller, cheaper and insensitive to magnetic field. Ultimately PET-MRI is expected to significantly reduce the 
radiation dose to patient, provide higher spatial resolution and superior soft tissue contrast. Such characteristics are invaluable for imaging systemic soft tissue disease and the brain. Areas such as Alzheimer's and Parkinson's disease and neuropsychiatric disorders such as schizophrenia and depression in particular, are expected to benefit from such developments.

\subsection{Animal PET cameras}

Dedicated animal PET (microPET) and PET-CT cameras have been available for some time. While they have proven to be useful for in vivo measurements of various physiological processes in small animals, there are a number of remaining challenges. Of these, spatial resolution, sensitivity and radiation dose are the most obvious. Currently high resolution microPET cameras have a maximum resolution of $\sim 1 \mathrm{~mm}$ (with ${ }^{18} \mathrm{~F}$ ) and a maximum sensitivity of almost 10\% (Lancelot, S. \& Zimmer, L., 2010). For animal cameras, positron energy and specific activity (i.e. radiolabelled product vs unradiolabelled product) of the radiopharmaceutical can have a detrimental effect on imaging resolution and sensitivity. In addition, CT scanners expose the animal to unnecessary additional high radiation dose. In contrast the PET-MRI systems are predicted to reduce this radiation exposure by up to $50 \%$. Unfortunately they are still under development and there are no commercial systems available at this time.

\section{Cyclotrons - How PET radioisotopes are produced}

PET radioisotopes are proton-rich and are predominantly produced using a cyclotron or linear accelerator (International Atomic Energy Agency, 2006; Schmor, P.W., 2010). The cyclotron was first conceived by Lawrence at Berkeley, USA in the early 1930s, and by the end of that decade it was producing radioisotopes for medical research. Over 15 years later there were cyclotrons in St Louis and Boston, USA and London, UK. The first company to produce cyclotrons, Scanditronix, was established in 1961, and today there are over 12 companies producing commercial cyclotrons. The design of a cyclotron can be quite varied and tailored to meet the specifications of the users.

Cyclotrons accelerate a beam of particles such as protons (p), deuterons (d), ${ }^{3} \mathrm{He}^{2+}$ or ${ }^{4} \mathrm{He}^{2+}$ $(\alpha)$ in a circular path, with protons being the most common particle used for radioisotope production. The particles need to reach certain energies $(\mathrm{MeV})$ for nuclear reactions to take place. The particle beam must also have sufficient current ( $\mu \mathrm{A} . \mathrm{hr}$ to $\mathrm{mA} . \mathrm{hr}$ ) to produce radioisotopes at reasonable quantities of radioactivity (e.g. $10 \mathrm{~s} \mathrm{GBq}$ to $10 \mathrm{~s} \mathrm{TBq}$ ) (International Atomic Energy Agency, 2009).

Today over 350 cyclotrons operate worldwide and most are devoted to radioisotope production (International Atomic Energy Agency, 2006; Petrusenko, Y.T. et al., 2009). More than half of these cyclotrons produce $\mathrm{p}$ with energies from 10 to $20 \mathrm{MeV}$ (majority of these $(\sim 75 \%)$ are designed to produce $18 \mathrm{~F})$, and others produce energies of up to $70 \mathrm{MeV}$. The number of cyclotrons is expected to increase in conjunction with the expanding role of PET and SPECT in molecular imaging.

The production of radioisotopes involves bombarding a target material with $\mathrm{p}, \mathrm{d},{ }^{3} \mathrm{He}^{2+}$ or $\alpha$ to cause a nuclear reaction to occur. Typically, these reactions involve a p entering the target nuclei and one or more neutrons $(n)$ or alphas $(\alpha)$ exiting with various gamma emissions. These nuclear reactions may be expressed in the following manner, $(p, 2 n),(p, x)$ and $(p, x n)$. 
Reactions with $\mathrm{d},{ }^{3} \mathrm{He}^{2+}$ or $\alpha$ less utilised, because the achievable energies and currents of their respective beams are comparatively lower than for protons.

\subsection{Cyclotron types}

Commercially available cyclotrons can be characterised into three types based on the energy of the particles they produce: (Schmor, P.W., 2010)

\subsubsection{Energies up to $20 \mathrm{MeV}$}

Often termed "baby" cyclotrons, they are the dominant producers of short lived PET isotopes (i.e. ${ }^{11} \mathrm{C},{ }^{18} \mathrm{~F},{ }^{13} \mathrm{~N}$, and ${ }^{15} \mathrm{O}$ ). They are generally located in hospital centres, a short distance from the PET camera. They produce beams of low currents $(<50 \mu \mathrm{A})$ and can handle a number of target types (typically gas or liquid and, more recently, solid targets). These cyclotrons can produce sufficient PET radiopharmaceuticals to support a number of PET cameras. The solid targets generally used to produce metal PET isotopes can be positioned external or internal (under vacuum) to the cyclotron, requiring extensive cooling systems.

\subsubsection{Energies 20-30 MeV}

These cyclotrons are used to produce both SPECT (e.g. ${ }^{67} \mathrm{Ga},{ }^{201} \mathrm{Tl},{ }^{111} \mathrm{In}$ and ${ }^{123} \mathrm{I}$ ) and PET radioisotopes. Gas, liquid and solid target systems are available. Beam currents are less than $50 \mu \mathrm{A}$ for gas and liquid, and up to $250 \mu \mathrm{A}$ for solid target systems. These cyclotrons are generally dedicated facilities, requiring highly skilled staff to maintain them. These production facilities can be located a substantial distance (i.e. different continents) from the nuclear medicine department.

\subsubsection{Energy 30-70 MeV}

High intensity and high energy cyclotrons are generally deployed for the production of large quantities of radioisotopes for sale. Those operating in the higher energy range are commonly used for research purposes. The recently commissioned $70 \mathrm{MeV}$ cyclotron at ARRONAX in France (Haddad, F. et al., 2008) will be used to produce radioisotopes for imaging and radiotherapy. They include, ${ }^{67} \mathrm{Cu},{ }^{211} \mathrm{At},{ }^{47} \mathrm{Sc}{ }^{52} \mathrm{Fe},{ }^{55} \mathrm{Co},{ }^{76} \mathrm{Br}$ and ${ }^{82} \mathrm{Sr}$. These radioisotopes can not be produced economically in lower energy systems. The selective production of a radioisotope, limiting the production of long lived contaminating radioisotopes, can be achieved with this system. For example, ${ }^{52} \mathrm{Fe}$ can be produced via ${ }^{55} \mathrm{Mn}(\mathrm{p}, 4 \mathrm{n}){ }^{52} \mathrm{Fe}$, and the long lived ${ }^{55} \mathrm{Fe}\left(\mathrm{T}_{1 / 2}=2.74\right.$ years $)$ is co-produced, however using a different reaction, such as ${ }^{50} \mathrm{Cr}(\alpha, 2 \mathrm{n})^{52} \mathrm{Fe}$ the production of ${ }^{55} \mathrm{Fe}$ is eliminated. The range of beam particles and their respective currents for this cyclotron are summarised in Table 2.

\begin{tabular}{|c|c|c|c|}
\hline Beam & $\begin{array}{c}\text { Accelerated } \\
\text { particles }\end{array}$ & $\begin{array}{c}\text { Energy range } \\
(\mathrm{MeV})\end{array}$ & $\begin{array}{c}\text { Intensity } \\
(\mu \mathrm{A})\end{array}$ \\
\hline $\mathrm{p}$ & $\begin{array}{c}\mathrm{H}^{-} \\
\mathrm{HH}^{+}\end{array}$ & $\begin{array}{c}30-70 \\
17.5\end{array}$ & $\begin{array}{c}<350(\mathrm{x} 2) \\
<50\end{array}$ \\
\hline $\mathrm{d}$ & $\mathrm{D}^{-}$ & $15-35$ & $50^{a}$ \\
\hline$\alpha$ & $\mathrm{He}^{++}$ & 70 & $<35$ \\
\hline
\end{tabular}

a Local radioprotection authorities in France set the intensity limit for deuterons.

Table 2. Characteristics of the beams for $70 \mathrm{MeV}$ Cyclotron ARRONAX, France 


\section{Factors governing selection of a radioisotope}

Historically, the criteria governing the selection of a PET radioisotope has been relatively simple and largely dominated by the availability, production yield and ability to image. Significant advances in design and stability of cyclotrons, cameras and data processing, has increased the potential range of PET radioisotopes. Today, the choice of PET radioisotopes is influenced by many factors (see Figure 2). It is important to understand how they impact on the production and clinical setting as well as on patients when administered repeatedly.

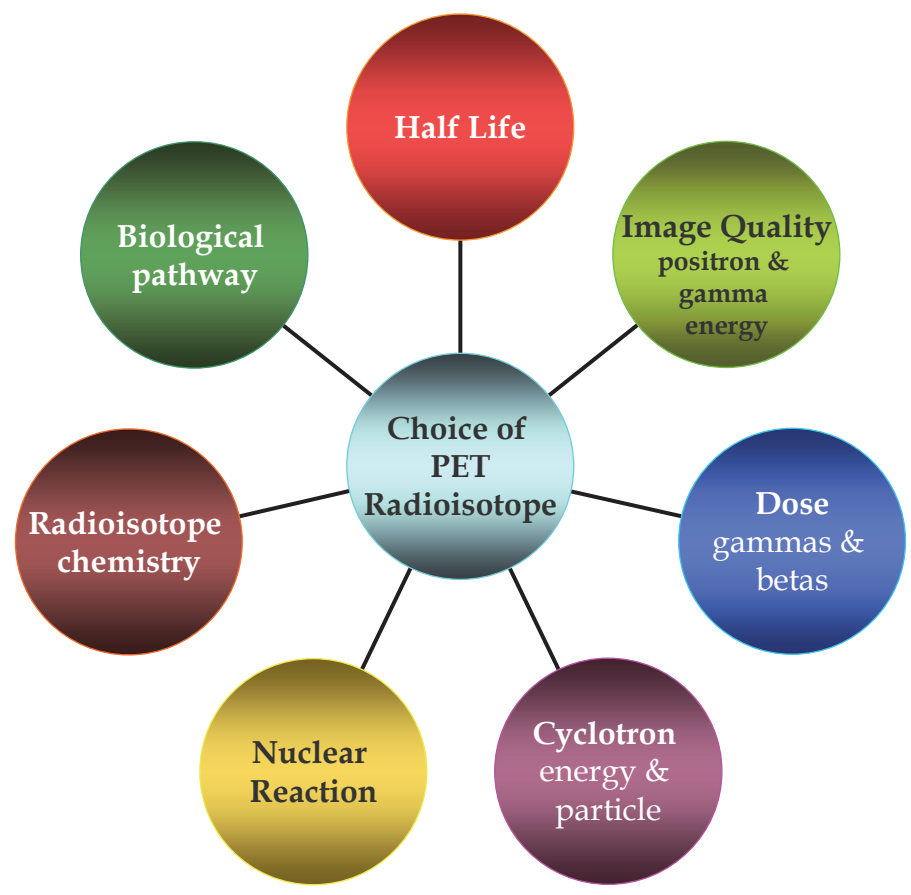

Fig. 2. Criteria governing selection of a PET radioisotope.

\subsection{Half life}

The half life of the PET radioisotope needs to match the biological half life of the carrier agent. For applications in diagnosis, this may simply be a radioisotope with a half life long enough to see the radiopharmaceutical accumulate in the diseased tissue and clear from blood. When imaging to determine prognosis of a patient (ability to respond to treatment) or assessing risk (therapeutic index) of an agent, the half life may need to be longer. For the latter, understanding uptake and clearance from all critical organs for a patient is important when determining its therapeutic index and or appropriate dose.

\subsection{Image quality}

The decay characteristics of the radioisotopes need to match the performance of the imaging camera. The resolution of PET remains dependent on three fundamental factors: 
1. Non-collinearity of annihilating gammas (i.e. deviation from $180^{\circ}$ angle on emission of $511 \mathrm{keV}$ signal)

2. Positron energy spectrum

3. Gamma emissions

\subsubsection{Positrons}

Non-collinearity can be reduced by bringing the detectors closer together. The higher the positron energies, the further they need to travel to lose enough energy to form a positronium, and this can cause images to blur (Pimlott, S.L. \& Sutherland, A., 2011). For human PET and particularly TOF-PET systems, the tolerance for the range of positron energies is higher than that of an animal PET camera. The spatial resolution of animal PET cameras is dependent on the maximum positron energy and its spectrum. Therefore in designing animal PET studies one needs to take into consideration the positron energy of the PET isotope.

\subsubsection{Gamma emissions}

Gamma emissions from the PET radioisotopes, of specified energies (and intensities), can interfere with the image quality, particularly those emitted within the PET discriminator window (ie. 350 and $700 \mathrm{keV}$ ). This leads to gamma coincidences that result in images of poor quality and flat unstructured background.

\subsection{Dose}

PET radioisotopes may decay via a number of pathways and give off $x$-rays, betas (i.e. electrons or positrons) and gammas. All of these emissions contribute to the total absorbed dose to the subject. From a production and imaging point of view it is the high intensity gamma emissions that cause concern for operators (i.e. production and animal handling staff) and applications in the clinical setting. Most PET facilities have been designed to handle ${ }^{18} \mathrm{~F}$ and do not have sufficient shielding for high energy gammas Where the patient is concerned, the presence of high energy gammas prevents re-injection (such as that used in cardiology) due to accumulated radiation dose.

\subsection{Cyclotron energy}

Cyclotrons need to produce a beam of suitable particles at a desired energy and current for the preferred nuclear reaction. Inappropriate beam characteristics will prevent operators from producing sufficient quantities for clinic applications.

\subsection{Nuclear reaction}

Most PET radioisotopes are produced by bombarding a target material, which often is isotopically enriched. An enriched target is expensive (up to $\$ 1000$ s per target irradiation). As only a negligible $(\sim 0.01 \%)$ portion of the target material is converted to the desired radioisotope, the target should be treated as an asset and recycled. Sometimes long lived gamma emitting radioisotopes can not be chemically removed. Their presence in the used target material can prevent its recycling in a timely manner. In such circumstances, a sizeable inventory of enriched target material needs to be purchased (e.g. $>\$ 250,000$ US) to permit decay of contaminants prior to reuse. 


\subsection{Chemistry of the PET radioisotope}

The ease, efficiency and cost of production of a PET radiopharmaceutical are affected by the chemistry of the radioisotope. The first aspect is the chemical separation of the PET radioisotope from the target material; this is more easily achieved if the target element is chemically different from the radioisotope. The separation process is generally conducted at the cyclotron site.

The second aspect of PET radiopharmaceutical production is the incorporation of the PET radioisotope into the carrier agent. Such processes must be performed relatively quickly and preferably quantitatively in order to produce high specific activity products. The production of the radiopharmaceutical may require hot-cells and/or an automated system. This can add considerable cost to the process and prevent production of the desired PET radiopharmaceutical at the site of use.

\subsection{Biological pathway}

Each radioisotope needs to be stably secured to a carrier. However, if the radiolabelled carrier breaks down in vivo it is likely to release the radioisotope. As radioisotopes mimic their naturally occurring metal ions, they can be expected to excrete from the body using normal biological pathways. Hence in choosing the radioisotope, one needs to consider these pathways and their potential contribution to the radiation dose to patient. For example, copper excretes via the liver and can be recirculated with ceruloplasmin. All the copper isotopes, ${ }^{60} \mathrm{Cu},{ }^{61} \mathrm{Cu},{ }^{62} \mathrm{Cu}$ and ${ }^{64} \mathrm{Cu}$ are expected to behave in a similar manner. In contrast, ${ }^{86} \mathrm{Y}$, like other lanthanides, will accumulate in bone while the biological pathway of ${ }^{89} \mathrm{Zr}$ is not known and therefore its behaviour is difficult to predict.

\section{Metal PET radioisotopes}

As mentioned previously the greatest potential for the PET radioisotopes is to provide diagnostic information on pathological processes and any changes to them, prior to anatomical changes. They have a significant role to play in both the screening of new diagnostic and therapeutic target agents in animal studies and in clinical trials. By radiolabelling the target agent, such as antibodies, the PET radiopharmaceuticals are used to determine the therapeutic index (distribution) of the antibody, the appropriate dose for the patient and also assist in selecting patients likely to respond to treatment.

Radiometal isotopes can also be incorporated into a ligand or complexing agent and used to monitor various biological properties such as blood flow, hypoxia or glomerular filtration and or organ function (e.g. heart, kidney or liver) (Smith, S.V., 2004 and references within). In this case, the design of the ligand and the resultant metal complex dictates the function of the PET radiopharmaceutical.

If the ligand is bi-functional, one portion of the molecule will be responsible for complexing the metal radioisotope and the other will contain a reactive group (e.g. amino, carboxylic acid or isothiocyanate) that is responsible for coupling the metal complex to a target agent. For target agents with long biological half lives (i.e. hours and days) it is important to ensure the radiolabel is secured and stable in vivo until the target agent clears from the body. This ensures the PET signal in vivo is from the radiolabelled target agent and not the radioisotope in its ionic state or non-specifically bound to naturally occurring biological components. Furthermore, the half life of the radioisotope needs to be sufficiently long enough to monitor the localisation of its carrier to the disease site and attain a signal to noise ratio of at least 2 fold. Table 3 summarises metal PET radioisotopes reported for these applications. 


\begin{tabular}{|c|c|c|c|c|c|}
\hline Isotope & Half Life & $\begin{array}{l}\text { Maximum } \beta+ \\
\text { Energy }(\mathrm{keV})\end{array}$ & $\begin{array}{c}\text { Mean } \beta+ \\
\text { Energy }(\mathrm{keV}) \\
\end{array}$ & $\begin{array}{c}\beta+\text { Intensity } \\
(\%)\end{array}$ & $\begin{array}{c}\gamma \text { energy } \\
(\mathrm{keV})(\text { Intensity \%) }\end{array}$ \\
\hline${ }^{48} \mathrm{~V}$ & $16.0 \mathrm{~d}$ & 695 & 290 & 49.9 & 944 (7.9); 984 (100); 1312 (98.2) \\
\hline${ }^{52} \mathrm{Fe}$ & $8.3 \mathrm{~h}$ & 804 & 340 & 55.0 & $169(99.2) ; 338(1.6)$ \\
\hline $52 \mathrm{~m} \mathrm{Mn}$ & $21.1 \mathrm{~m}$ & 2633 & 1174 & 94.8 & $1434(98.3)$ \\
\hline${ }^{52} \mathrm{Mn}$ & $5.6 \mathrm{~d}$ & 576 & 242 & 29.6 & $\begin{array}{c}744(90.0) ; 848(3.3) ; 936(94.5) \\
1434(100.0)\end{array}$ \\
\hline${ }^{55} \mathrm{Co}$ & $17.5 \mathrm{~h}$ & $\begin{array}{l}1021 \\
1113 \\
1499\end{array}$ & $\begin{array}{l}436 \\
476 \\
649\end{array}$ & $\begin{array}{c}25.6 \\
4.3 \\
46.0\end{array}$ & $\begin{array}{c}477(20.2) ; 931(75.0) ; 1317(7.1) \\
1409(16.9)\end{array}$ \\
\hline${ }^{60} \mathrm{Cu}$ & $23.7 \mathrm{~m}$ & $\begin{array}{l}1835 \\
1911 \\
1981 \\
2946 \\
3772\end{array}$ & $\begin{array}{c}805 \\
840 \\
872 \\
1325 \\
1720\end{array}$ & $\begin{array}{c}4.6 \\
11.6 \\
49.0 \\
15.0 \\
5.0\end{array}$ & $\begin{array}{c}467 \text { (3.5); } 826(21.7) ; 1035(3.7) ; \\
1333 \text { (88.0); } 1792 \text { (45.4); } 1862(4.8) ; \\
3124(4.8)\end{array}$ \\
\hline${ }^{61} \mathrm{Cu}$ & $3.3 \mathrm{~h}$ & $\begin{array}{c}559 \\
932 \\
1148 \\
1215\end{array}$ & $\begin{array}{l}238 \\
399 \\
494 \\
524\end{array}$ & $\begin{array}{c}2.6 \\
5.5 \\
2.3 \\
51.0\end{array}$ & $283(12.2) ; 656(10.8) ; 1185(3.7)$ \\
\hline${ }^{62} \mathrm{Zn}$ & $9.3 \mathrm{~h}$ & 605 & 259 & 8.4 & $508(14.8) ; 548(15.3) ; 597(26.0)$ \\
\hline${ }^{62} \mathrm{Cu}$ & $9.7 \mathrm{~m}$ & 2926 & 1316 & 97.2 & \\
\hline${ }^{63} \mathrm{Zn}$ & $38.5 \mathrm{~m}$ & $\begin{array}{l}1382 \\
1675 \\
2345\end{array}$ & $\begin{array}{c}600 \\
733 \\
1042\end{array}$ & $\begin{array}{c}4.9 \\
7.0 \\
80.3\end{array}$ & $670(8.2) ; 962(6.5)$ \\
\hline${ }^{64} \mathrm{Cu}$ & $12.7 \mathrm{~h}$ & 653 & 278 & 17.6 & \\
\hline${ }^{66} \mathrm{Ga}$ & $9.5 \mathrm{~h}$ & $\begin{array}{c}924 \\
4153\end{array}$ & $\begin{array}{c}397 \\
1904 \\
\end{array}$ & $\begin{array}{c}3.7 \\
51.0 \\
\end{array}$ & $\begin{array}{c}834(5.9) ; 1039(37.0) ; 2190(5.3) \\
2752(22.7) ; 4295(3.8)\end{array}$ \\
\hline${ }^{68} \mathrm{Ga}$ & $1.1 \mathrm{~h}$ & $\begin{array}{c}822 \\
1899 \\
\end{array}$ & $\begin{array}{l}353 \\
836 \\
\end{array}$ & $\begin{array}{c}1.2 \\
87.9 \\
\end{array}$ & $1077(3.2)$ \\
\hline${ }^{81} \mathrm{Rb}$ & $4.6 \mathrm{~h}$ & $\begin{array}{c}580 \\
1026 \\
\end{array}$ & $\begin{array}{l}254 \\
448\end{array}$ & $\begin{array}{c}1.8 \\
25.0\end{array}$ & $190(64.0) ; 446(23.3) ; 510(5.3)$ \\
\hline${ }^{82} \mathrm{Rb}$ & $1.3 \mathrm{~m}$ & $\begin{array}{l}2601 \\
3378 \\
\end{array}$ & $\begin{array}{l}1168 \\
1535\end{array}$ & $\begin{array}{l}13.1 \\
81.8\end{array}$ & $777(15.1)$ \\
\hline${ }^{83} \mathrm{Sr}$ & $1.4 \mathrm{~d}$ & $\begin{array}{c}830 \\
1212\end{array}$ & $\begin{array}{l}363 \\
531\end{array}$ & $\begin{array}{l}3.1 \\
9.0\end{array}$ & $382(14.0) ; 418(4.4) ; 763(30.0)$ \\
\hline${ }^{86} \mathrm{Y}$ & $14.7 \mathrm{~h}$ & $\begin{array}{l}1221 \\
1545 \\
1988 \\
3141\end{array}$ & $\begin{array}{c}535 \\
681 \\
883 \\
1437\end{array}$ & $\begin{array}{l}11.9 \\
5.6 \\
3.6 \\
2.0\end{array}$ & $\begin{array}{c}515(4.9) ; 581(4.8) ; 628(32.6) ; \\
646(9.2) ; 703(15.4) ; 777(22.4) ; \\
836(4.4) ; 1077(82.5) ; 1153(30.5) ; \\
1443(16.9) ; 1854(17.2) ; 1921 \\
(20.8)\end{array}$ \\
\hline${ }^{89} \mathrm{Zr}$ & $78.4 \mathrm{~h}$ & 902 & 396 & 22.7 & $909(99.0)$ \\
\hline $94 \mathrm{mTc}$ & $52.0 \mathrm{~m}$ & 2439 & 1094 & 67.6 & $871(94.2) ; 1522(4.7) ; 1869(5.7)$ \\
\hline${ }^{94} \mathrm{Tc}$ & $4.9 \mathrm{~h}$ & 811 & 358 & 10.5 & $\begin{array}{c}703(99.6) ; 850(95.7) ; 871(99.9) \text {; } \\
916(7.6)\end{array}$ \\
\hline${ }^{110}$ In & $1.2 \mathrm{~h}$ & 2260 & 1043 & 62.0 & $658(98.0)$ \\
\hline
\end{tabular}

Table 3. Selection of Metal PET radioisotopes and their physical characteristics (http://www.nndc.bnl.gov/; International Atomic Energy Agency, 2009) 
Their physical characteristics including mean positron energy, gamma emissions and half lives are given. Only gamma emissions of greater than $5 \%$ intensity, or that are within the PET detector window, or contribute significantly to operator dose have been included. All of the radioisotopes listed emit positrons of sufficient energy and intensity (> 10\%) for imaging with available PET cameras. Further each radioisotope listed can be produced in commercially available cyclotrons.

\subsection{Half life}

The half lives of the radioisotopes presented in Table 3 vary from minutes to days. They may be classified into groups based on these half lives (see Figure 3). The timeframes chosen take into consideration the time to purify the radioisotopes, its incorporation into a carrier agent and the packaging and transport of the resultant radiopharmaceutical across continents.

The first class of radioisotope $\left(t_{1 / 2}=1-60\right.$ mins $)$ is generally used as surrogates for cations in vivo or incorporated into complexing agents. A number of the radioisotopes can be produced from a generator system (see Figure 4) making them more accessible to the wider PET community. Radioisotopes with longer half lives (hours to days) are best suited for studying the pharmacokinetics or dynamics of large molecules such as peptides, proteins and particles.

There are 6 PET radioisotopes $\left({ }^{82} \mathrm{Rb},{ }^{62} \mathrm{Cu}, 52 \mathrm{mMn},{ }^{60} \mathrm{Cu},{ }^{63} \mathrm{Zn}\right.$ and $\left.{ }^{94 \mathrm{~m} T c}\right)$, with half lives varying from $1.3-52 \mathrm{~min}$. Three, ${ }^{82} \mathrm{Rb},{ }^{62} \mathrm{Cu}$ and $52 \mathrm{mMn}$ are particularly attractive because they can be produced from a generator utilising the decay of ${ }^{82} \mathrm{Sr},{ }^{62} \mathrm{Zn}$ or ${ }^{52} \mathrm{Fe}$ to produce the respective daughter PET radioisotopes (see Figure 4). The ${ }^{82} \mathrm{Sr} / 82 \mathrm{Rb}$ and ${ }^{62} \mathrm{Zn} /{ }^{62} \mathrm{Cu}$ generators have been commercially available for some time. The radioisotopes ${ }^{60} \mathrm{Cu},{ }^{63} \mathrm{Zn}$ and $94 \mathrm{mTc}$ must be produced and used at or within a short distance from the cyclotron production centres.

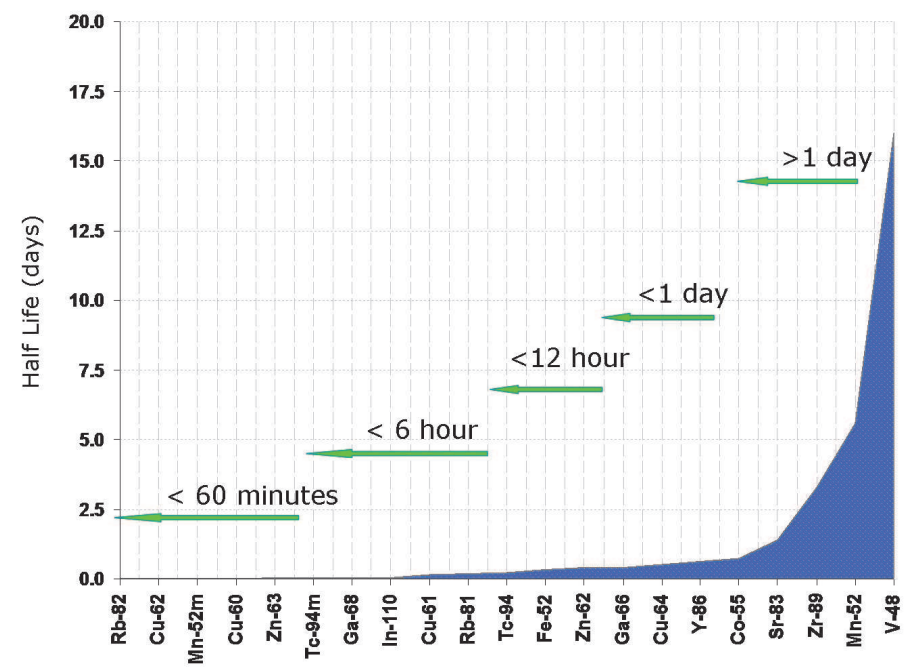

Fig. 3. Classification of positron emitting radioisotopes. 


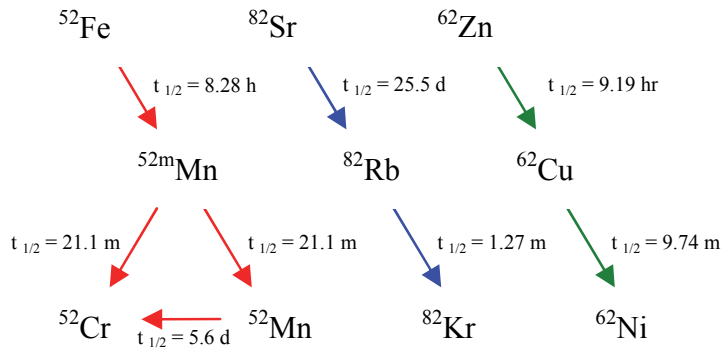

Fig. 4. Decay scheme for generator produced ${ }^{52 \mathrm{~m}} \mathrm{Mn},{ }^{82} \mathrm{Rb}$ and ${ }^{62} \mathrm{Cu}$

For example, ${ }^{82} \mathrm{Rb}^{+}\left(\mathrm{t}_{1 / 2}=1.3 \mathrm{~min}\right)$ is used in myocardial perfusion studies; it acts as a surrogate for $\mathrm{K}^{+}$. The very short half life of ${ }^{82} \mathrm{Rb}$ makes whole body imaging a challenge and precludes imaging after 10 mins. As a result activities of up to $1.5 \mathrm{GBq}$ are administered to patients. Heart, kidney, lungs and pancreas receive an absorbed radiation dose of 5.1, 5.0, 2.8 and $2.4 \mathrm{mGy}$ per MBq, respectively. This is significantly less than both ${ }^{201} \mathrm{Tl}$ and $99 \mathrm{mTc}$ sestamibi SPECT agents (Senthamizhchelvan, S. et al., 2011). The long half life of the parent ${ }^{82} \mathrm{Sr}\left(\mathrm{t}_{1 / 2}=25.55\right.$ days) permits its transport throughout the world.

The radioisotopes ${ }^{60} \mathrm{Cu}\left(\mathrm{t}_{1 / 2}=23.7 \mathrm{~min}\right)$ and ${ }^{62} \mathrm{Cu}\left(\mathrm{t}_{1 / 2}=9.6 \mathrm{~min}\right)$ have identical chemistry and can be interchanged depending on the carrier agent and the biological processes under investigation. The ${ }^{62} \mathrm{Cu}$ is produced from the parent ${ }^{62} \mathrm{Zn}\left(\mathrm{T}_{1 / 2}=9.3 \mathrm{hour}\right)$; its short half life requires the generator to be prepared daily.

The story with $52 \mathrm{mMn}$ is more complex. It is produced from the positron-emitting parent ${ }^{52} \mathrm{Fe}$ $\left(\mathrm{t}_{1 / 2}=8.3\right.$ hours) and then decays by positron emission to the long-lived daughter ${ }^{52 \mathrm{Mn}}$

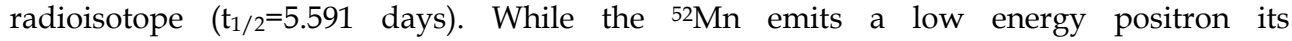
extraordinarily high energy gamma detracts from its use in PET imaging. A recent study, investigating the effect of the daughter ${ }^{52} \mathrm{mMn}$ on the ${ }^{52} \mathrm{Fe}$ PET image quality showed there was minor degradation, compared to ${ }^{18} \mathrm{~F}$.

The positron energies for ${ }^{60} \mathrm{Cu}$ and ${ }^{63} \mathrm{Zn}$ are of similar intensity, the latter having comparatively less gamma emissions. It is surprising ${ }^{63 \mathrm{Zn}}$ has not been reported in the literature more often. As $\mathrm{Cu}(\mathrm{II})$ and $\mathrm{Zn}$ (II) complex with similar chelating agents, there is potential to substitute ${ }^{63} \mathrm{Zn}$ for ${ }^{60} \mathrm{Cu}$ in emerging blood flow or hypoxia markers.

Technetium-94m also has a short half life with a relatively high intensity positron emission. It decays to the positron emitter ${ }^{94} \mathrm{Tc}$, which further decays giving off a large proportion of high energy gammas. The ${ }^{94 \mathrm{mTc}}$ could potentially act as a surrogate for the SPECT $99 \mathrm{mTc}$ agents but negligible improvement in imaging resolution is unlikely to compensate for the increased dose both to operator and subject.

The application of radioisotopes ranging in half life from 1 hour to less than a day is varied. They are readily incorporated into chelators or carrier agents but their stability will be dependent on their respective coordination chemistry and redox chemistry. Generator produced ${ }^{68} \mathrm{Ga}\left(\mathrm{t}_{1 / 2}=1.1\right.$ hours) has been used to radiolabel a range of peptides including derivatives of octreotide (Gabriel, M. et al., 2007; Henze, M. et al., 2001) and arginineglycine-aspartate (RGD) (Li, Z.B. et al., 2008; Liu, Z.F. et al., 2009). However, the short half life of ${ }^{68} \mathrm{Ga}$ can create challenges for the synthesis of the radiopharmaceutical and its imaging. The high energy positrons given off by ${ }^{110} \mathrm{In}$ and ${ }^{66} \mathrm{Ga}$ would prohibit their use as surrogates for ${ }^{111} \mathrm{In}$ and ${ }^{67} \mathrm{Ga}$ SPECT agents, while their high intensity gammas ( 1 to $\left.4 \mathrm{MeV}\right)$ require considerably more lead shielding for handling than classical PET agents. 
All PET isotopes with half lives greater than 12 hours have greater flexibility in PET imaging. Of the radioisotopes selected ${ }^{64} \mathrm{Cu},{ }^{89} \mathrm{Zr}$ and ${ }^{48} \mathrm{~V}$ have the most favourable positron energies for imaging but only ${ }^{64} \mathrm{Cu}$ does not have significant gammas to compromise its application.

\subsection{Gamma emissions - Safety}

As mentioned previously, some gamma emissions from the PET isotopes can affect PET image quality, choice of shielding in production facilities and cause unnecessary absorbed dose to the subject. Shielding suitable for ${ }^{18} \mathrm{~F}$ may not be sufficient to shield gammas with energies significantly greater than $500 \mathrm{keV}$ (Madsen, M.T. et al., 2006). Figure 5 illustrates a simple comparison of the relative energy and the intensities of gammas emitted from some of the radioisotopes given in Table 3. The data clearly show that gammas generated from the decay of ${ }^{60} \mathrm{Cu},{ }^{86} \mathrm{Y}$ and ${ }^{89} \mathrm{Zr}$ are of significantly higher energies than that of ${ }^{18} \mathrm{~F}$; therefore these radioisotopes will require substantially more lead shielding for processing compared to that used for ${ }^{18} \mathrm{~F}$ productions. Gammas in the range of $350-700 \mathrm{keV}$ (shaded green on image) from decay of ${ }^{62} \mathrm{Zn}$ and ${ }^{86} \mathrm{Y}$ will interfere with PET image quality, resulting in a reduced signal to noise ratio. In stark contrast, ${ }^{62} \mathrm{Cu}$ and ${ }^{64} \mathrm{Cu}$ have no significant gammas that will interfere with camera quality, nor do they require significant changes to current lead shielding used in PET facilities.

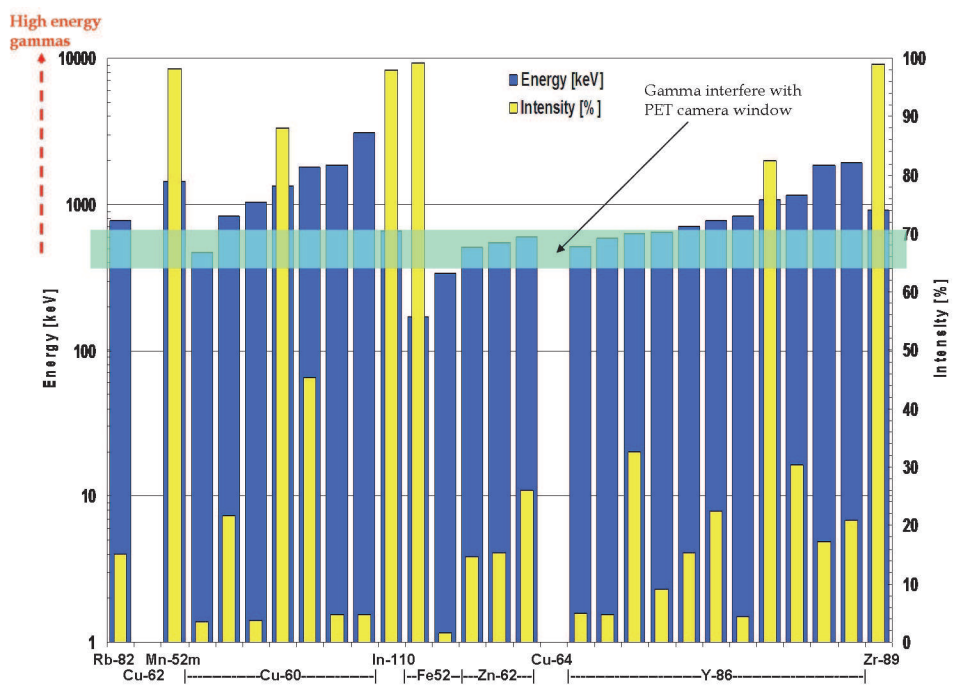

Fig. 5. Compares relative gamma emissions (blue) and their intensities (yellow) for selected radioisotopes from Table 3 .

\section{Radiation dose}

As the energy and the probability of gamma emissions is specific for each radioisotope, they can be used to calculate the energy released per decay in the form of photons. The energy released per decay may be represented as $\mathrm{MeV}(\mathrm{Bq} \mathrm{s})^{-1}$, where $1 \mathrm{~Bq}=1$ decay per second. 
Radiation dose received by an operator or patient is measured in Sievert, Sv. One Sv is equivalent to the energy absorbed per kilogram of mass $(\mathrm{J} / \mathrm{kg})$. In the case of the operator who is positioned at some distance from the radiation source, the dose received in Sv is a function of the intensity of the radiation, type of radiation, distance from the source and the time exposed to the source. It is convenient to discuss the dose rate in Sv/hr, so that the operator can determine the dose received for a specific time period.

Figure 6 illustrates the dose rate per unit of radioactivity received by an operator at one metre distance from each unshielded PET radioisotope source. It shows the effect of high energy gammas can vary by 10 -fold across the series of radioisotopes listed in Table 3 . These doses also need to be considered when dispensing the radiopharmaceutical and when injecting the subject (i.e. patient or animal) as they effectively become a radioactive source and shielding under these circumstances is not always practical.

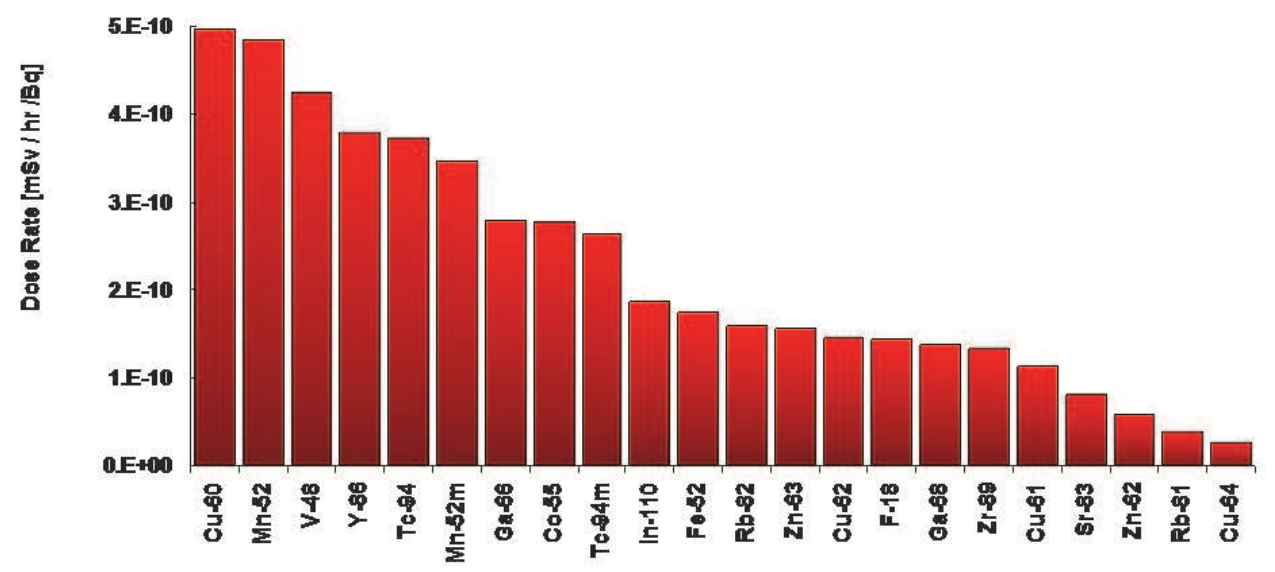

Fig. 6. The dose rate per unit of radioactivity received by an operator at one metre from an unshielded source.

\subsection{Shielding}

The dose rate values in Figure 6 can be used to determine the shielding for the production, handling and storage of the PET isotopes. The shielding can then be adjusted to ensure the radiation exposure to the operator is kept within an acceptable level. The following relationship can be used to determine the shielding required:

$$
\mathrm{I}=\mathrm{I}_{0} \mathrm{e}^{-\mu_{\mathrm{t}}}
$$

where:

I = intensity of the radiation after shielding,

$\mathbf{I}_{0}=$ intensity before shielding,

$\mathbf{t}=$ thickness $[\mathrm{cm}]$ of shielding material (in this case lead), and

$\mu=$ linear attenuation coefficient $\left[\mathrm{cm}^{-1}\right]$.

The linear attenuation coefficient takes into account the effect of photoelectric absorption, Compton collision, pair production and Rayleigh scattering. The relationship between linear 
attenuation and the energy coefficients for a range of photon energies is illustrated in Figure 7 (Hubbell, J.H., 1969). The curve shows that for higher energy gammas travelling through lead, the attenuation is lower per unit of distance travelled. As a result, for the same intensity of radiation, a greater thickness of lead is required to shield an operator from higher energy photons than for lower energy photons.

Photoelectric effect, Compton scattering and pair production can result in secondary photons. These photons have a finite probability of contributing to the total dose received by the operator. The extent to which these secondary photons contribute is described through the use of a build-up factor. For simplification this will be ignored here, but it should be noted that it is a multiplicative factor, that is, always greater than one. Further the multiplication factor is dependent on the energy of the incident photons, the atomic number of the shielding material and the thickness of the shielding. For further information regarding shielding calculations refer to Principles of Radiation Shielding (Chilton, A.B. et al., 1984). To calculate the thickness of lead required to shield an operator for a quantity of radioactivity, the radiation is assumed to be at the highest energy gamma associated with the radioisotope decay. Further if we set the maximum permitted operator dose at $12 \mathrm{mSv}$ per working year, the maximum dose rate for operator exposure is $\sim 0.00625 \mathrm{mSv} / \mathrm{hr}$ where one year is equivalent to $48 \mathrm{wks}$ at 40 hours/wk.

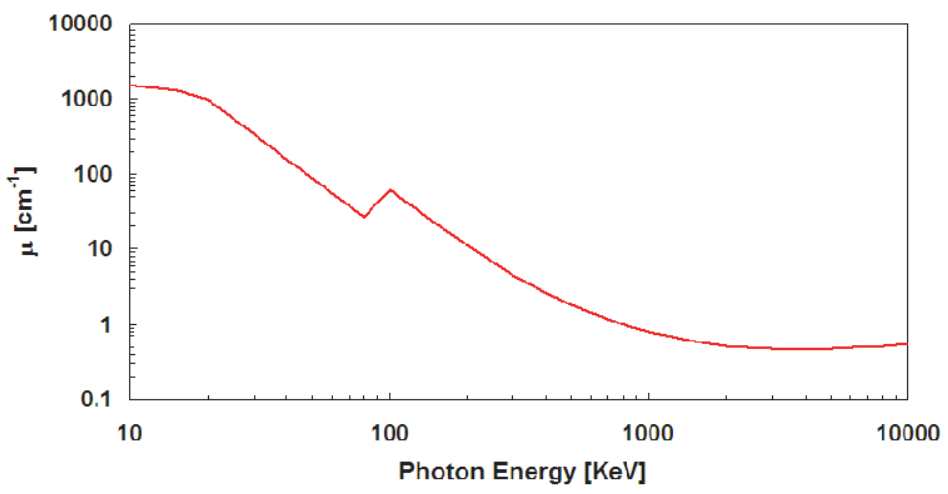

Fig. 7. Log-Log plot of linear attenuation coefficients for lead as a function of energy.

To obtain the thickness of lead required to reduce the original intensity $\mathbf{I}_{0}$ to the desired value I, equation (1) is rearranged to:

$$
\mathrm{t}=-(\mu)^{-1} \ln \left(\mathrm{I} / \mathrm{I}_{0}\right)[\mathrm{cm}]
$$

Assuming the source has $1 \mathrm{Ci}(37 \mathrm{GBq})$ of a PET radioisotope, the thickness of lead required to reduce the operator dose rate to $0.00625 \mathrm{mSv} / \mathrm{hr}$ may be calculated using (2). It is useful to combine the data of Figure 6 with Figure 7 and compare the dose rate per activity plotted with the relative thickness of required lead shielding to reduce the dose to specified levels in Figure 8. In other words, the data show the relative thickness of shielding for the same amount of radioactivity for each PET isotope. For ${ }^{60} \mathrm{Cu}$, a 5 fold greater thickness of lead shielding is required compared to an equivalent amount of ${ }^{64} \mathrm{Cu}$ radioactivity. 
It is important however to note that the relative order of shielding required for each PET radioisotope in Figure 8 does not always correspond directly to the total dose rate discussed above. For example, shielding for ${ }^{86} \mathrm{Y},{ }^{66} \mathrm{Ga},{ }^{55} \mathrm{Co},{ }^{94} \mathrm{mTc},{ }^{63} \mathrm{Zn},{ }^{68} \mathrm{Ga},{ }^{89} \mathrm{Zr},{ }^{61} \mathrm{Cu},{ }^{83} \mathrm{Sr},{ }^{62} \mathrm{Zn},{ }^{81} \mathrm{Rb}$ and ${ }^{64} \mathrm{Cu}$ is significantly higher than one might have anticipated when examining only dose. In contrast, the shielding required for ${ }^{52 \mathrm{Mn}},{ }^{48 \mathrm{~V}},{ }^{94} \mathrm{Tc},{ }^{110} \mathrm{In},{ }^{52} \mathrm{Fe}{ }^{82} \mathrm{Rb}, 18 \mathrm{~F},{ }^{62} \mathrm{Cu}$ and ${ }^{68} \mathrm{Ga}$, are all lower. This emphasises the importance of considering dose and shielding together, even when the high energy gammas are of low intensity, when handling and administering the PET radiopharmaceuticals. These results concur with recently reported findings (Holland, J.P. et al., 2011) where the occupational exposure of staff increased when handling low amounts of activity ( 1-25 $\mathrm{mCi}$ ) of ${ }^{86} \mathrm{Y}$ and ${ }^{89} \mathrm{Zr}$ compared to significantly higher quantities of ${ }^{18} \mathrm{~F}$ activity $(\sim 400-500 \mathrm{mCi})$.

Furthermore, transport of these types of PET isotopes requires modification of shipment containers or significant reduction in the amount of activities to be shipped. The emission of high energy gammas from ${ }^{86} \mathrm{Y}$ and ${ }^{89} \mathrm{Zr}$ allow only $\sim 1 / 162$ and $\sim 1 / 44$ respectively of the maximum activity of $18 \mathrm{~F}$ to be transported in approved PET radioisotope shipment containers in the USA (Holland, J.P. et al., 2011). Negligible change in shielding would be required for ${ }^{64} \mathrm{Cu}$.

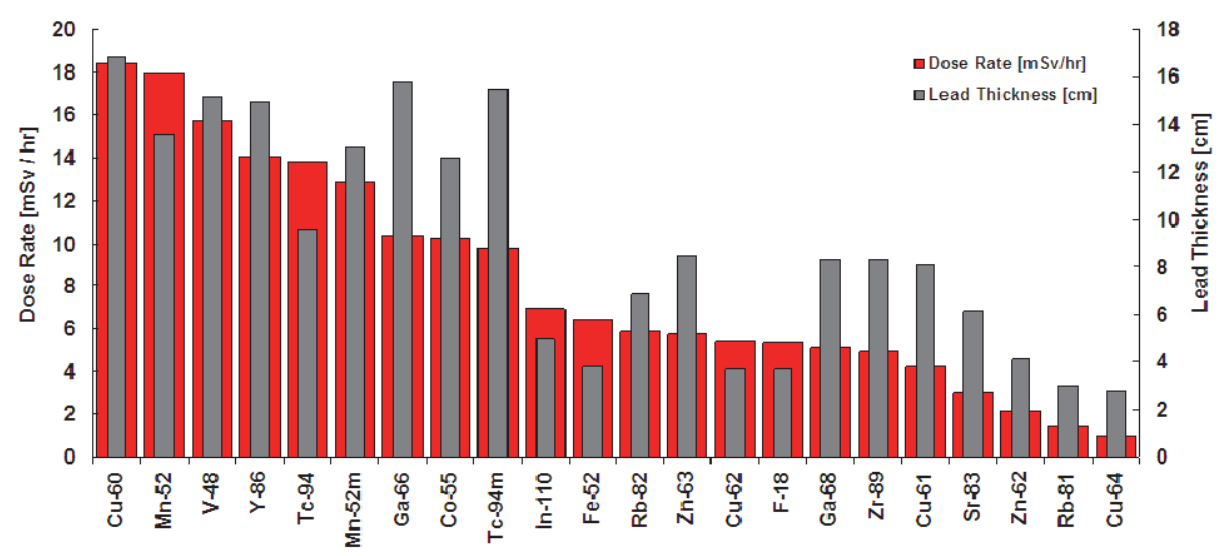

Fig. 8. Dose rate per unit activity and the required lead shielding for each PET radioisotope.

\section{Positron energy - Image quality}

It is important to consider the energies of the positrons emitted from the PET radioisotopes when determining their application. Because the positron has to lose energy before it annihilates, it travels and interacts with tissue over a significant range (i.e. millimetres). As the density of the tissue can affect the rate at which the energy is lost from the positron, one may also expect the positron to travel further in lung tissue (because it is predominantly air). PET images in this region will be "blurred" and the spatial resolution will be poorer compared to other parts of the body where the density of tissue is higher. In contrast, for bone, which is considered electron rich and of dense composition, the PET image appears comparatively sharper. 
For small animal PET cameras, PET radioisotopes emitting high energy positrons have a detrimental effect on image quality (Laforest, R. \& Liu, X., 2008; Partridge, M. et al., 2006). Laforest and Lui 2008, reported that both the range the positron travels and the presence of cascades of gamma rays contributed to poor signal to noise ratios. In the same work, they compare phantoms containing either ${ }^{60} \mathrm{Cu},{ }^{61} \mathrm{Cu},{ }^{64} \mathrm{Cu},{ }^{94 \mathrm{mTc}}$ or ${ }^{86} \mathrm{Y}$ and demonstrate how the positron energy can affect the image resolution.

Improvement in spatial resolution of animal PET cameras using these radioisotopes can be achieved by an increase in imaging time and a reduction in the coincidence window limits to prevent contamination from other decay modes (Vandenberghe, S., 2006). To do this the subject either needs to be injected with more radioactivity or kept in the field of view of the camera for longer periods of time. A more sophisticated approach to improve image quality is to develop image reconstruction algorithms that consider the nuclear decay and tomography response (Laforest, R. \& Liu, X., 2008; Ruangma, A. et al., 2006).

Though the development of cyclotrons continues to flourish and in parallel the range of PET isotopes, understanding the track structure of positrons emitted is largely unresolved. Attempts to use Monte Carlo modelling to illustrate the tracking of positrons in tissues have been made by a number of groups. Work by Sanchez-Crespo et al. (Sanchez-Crespo, A. et al., 2004) has shown how the density of tissue can change the resolution of an image. But such modelling is unlikely to comprehensively predict the positron behaviour or its microdosimetry, until accurate measurements of the cross sections for the interaction of positrons and electrons with various biological molecules have been attained. Such data have the potential to improve the analysis of PET data and therefore the quality of PET images, as well as improve accuracy of absorbed radiation dose calculations.

A closer examination of the PET radioisotopes considered in this chapter (see Table 3) shows that many of the isotopes can emit a number of positrons through the allowed decay paths. Understanding the kinetic energy spectra for each of these positrons is useful, as they affect the quality of the image to different degrees. In using equation 3 the positron energy spectra are calculated for the highest intensity positron per radioisotope in a similar manner to that reported by Le Loirec (Le Loirec, C. \& Champion, C., 2007a).

$$
\begin{gathered}
N(E)=C F(Z, E) p E\left(E_{\max }-E\right)^{2} \\
F(Z, E)=2 \pi \eta\left(1-e^{-2 \pi \eta}\right)^{-1} \\
\eta=-Z \alpha E / p
\end{gathered}
$$

Where:

$\mathrm{E}=$ total energy of the positron;

$\mathrm{Z}=$ atomic number;

$\mathrm{a}=$ fine structure constant;

$\mathrm{p}=$ momentum of positron;

$\mathrm{E}_{\max }=$ maximum allowed energy of positron;

$\mathrm{C}=$ normalisation constant.

The spectrum of the dominant positron emission for each radioisotope is illustrated in Figure 9. The data demonstrate the range of positron energies per isotope and therefore the relative distance they are likely to travel in vivo. Of course, these values do not take into account the tissue density, but they can be used to give an indication of the relative quality 
of images to be obtained for each PET radioisotope. The green shaded area represents the

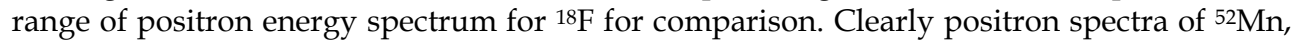
${ }^{62} \mathrm{Zn},{ }^{64} \mathrm{Cu}$ and ${ }^{48} \mathrm{~V}$ correlate best with ${ }^{18} \mathrm{~F}$ and potentially could give similar image quality. However the interfering gammas for all of these radioisotopes, except ${ }^{64} \mathrm{Cu}$, may compromise image quality.

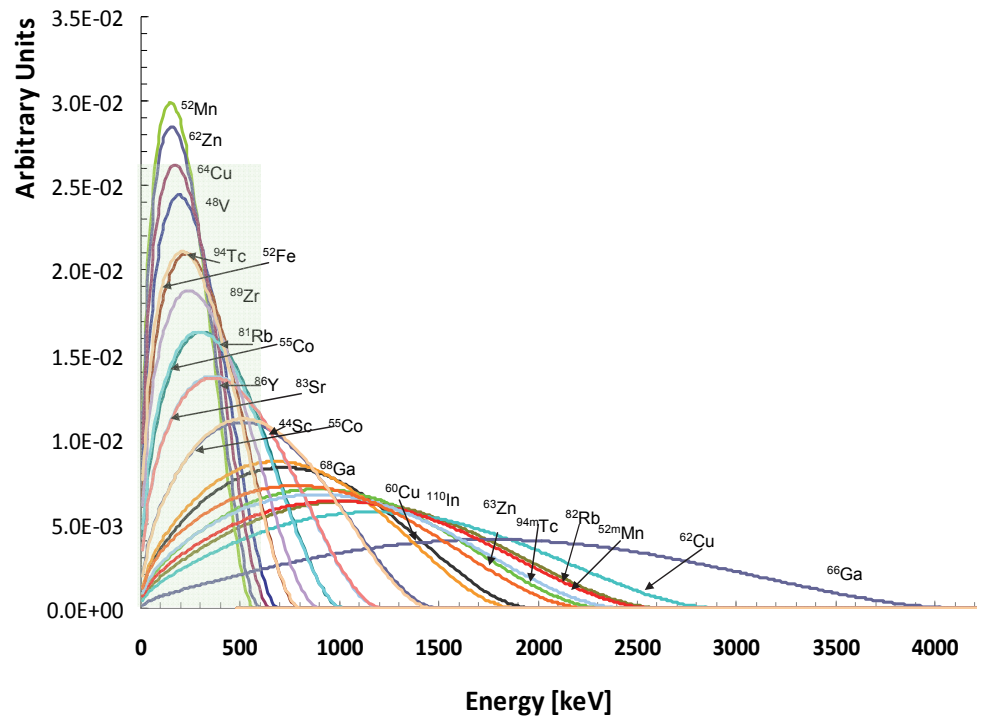

Fig. 9. The spectrum of the dominant positron emission for each radioisotope

Figure 10 (a) and (b) illustrate the relative intensity of kinetic energy spectra for $\beta^{+}$decays (in colour dotted curves) of ${ }^{61} \mathrm{Cu}$ and ${ }^{66} \mathrm{Ga}$ respectively. These spectra do not take into account the relative intensity of each positron. Conversely the black curve is the result of the accumulated spectra taking into consideration the relative intensities of each. Figure 10a shows how a low energy positron $(559 \mathrm{keV})$ can become insignificant when a high intensity of the higher energy positron $(1215 \mathrm{keV})$ is present. A similar effect is evident for ${ }^{66} \mathrm{Ga}$ however the shape is significantly different and suggests the signal to noise ratio would be poorer.

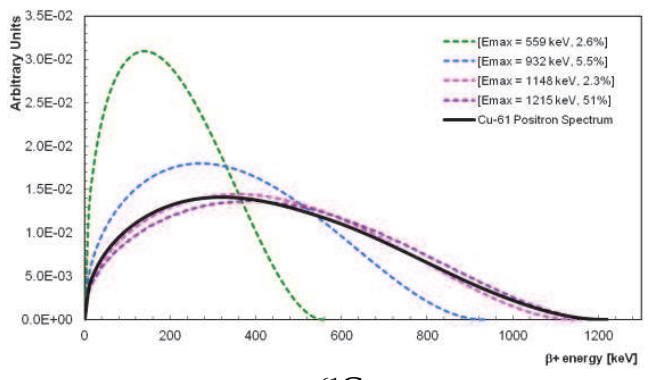

a ${ }^{61} \mathrm{Cu}$

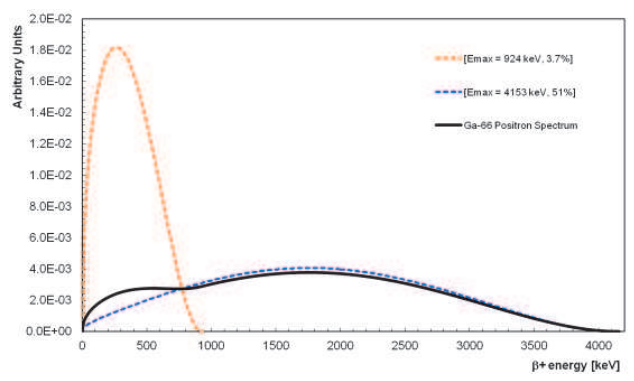

b $66 \mathrm{Ga}$

Fig. 10. The relative kinetic energy spectra of the positrons emitted by ${ }^{61} \mathrm{Cu}$ and ${ }^{66} \mathrm{Ga}$ (Le Loirec, C. \& Champion, C., 2007a; 2007b) 


\section{Production of metal positron emitting isotopes}

There are many radioisotopes that can be produced with a cyclotron. The challenge in each case is to develop targetry (target material and loading system) that allows it to be kept stable in the beam of the accelerated particles and to remove the desired radioisotope quickly and efficiently. Unlike the well-known PET isotopes ${ }^{11} \mathrm{C},{ }^{18} \mathrm{~F}$ and ${ }^{15} \mathrm{~N}$ which are produced using gas or liquid based targetry, the metal radioisotopes listed in Table 3 are mostly generated from solid targets of metal based materials (e.g. metal element or metal oxide). The target can be placed within the cyclotron (under vacuum) or external to the cyclotron. In each case the target system needs to tolerate heat generated from the particle reactions. Depending on the energy and current of the beam ( $\mu \mathrm{A}$ or $\mathrm{mA})$ the cooling systems can be quite elaborate.

As the number of nuclear reactions is potentially large, one needs to design the target so that the preferred nuclear reaction dominates. This may be achieved in a number of ways:

a. choice of beam particle [i.e. $p, d$, or $\alpha$ ]

b. energy of the beam

c. target material [i.e. natural or enriched isotope of target element].

The use of enriched isotopes for these types of reactions can add considerable cost to the production of a radioisotope. It is wise to treat the material as capital and recycle it for reuse. By using an enriched isotope for the target, one can also prevent or reduce the production of contaminating radioisotopes. If these contaminating radioisotopes have high gamma emissions or different half lives from the desired radioisotope, they can affect the shielding and timing of a production process, as well as delay the recycling of enriched target material. For example, ${ }^{67} \mathrm{Ga}$ is a SPECT agent produced by proton bombardment of enriched ${ }^{68} \mathrm{Zn}$. By-products of this reaction are ${ }^{66} \mathrm{Ga}\left(\mathrm{t}_{1 / 2}=9.5 \mathrm{hr}\right)$ and ${ }^{65} \mathrm{Zn}\left(\mathrm{t}_{1 / 2}=244\right.$ days), both of which produce high energy gammas. The former is often left to decay before the ${ }^{67} \mathrm{Ga}$ can be processed. Furthermore shielding of hot cells needs to be increased to reduce the dose to operators. The presence of the latter, $65 \mathrm{Zn}$, prevents recycling of the ${ }^{68} \mathrm{Zn}$ target material. Therefore, large inventories $(\sim 100 \mathrm{~g}$ costing $\sim \$ 250,000$ US) of enriched $68 \mathrm{Zn}$ is maintained so irradiated samples can be left to decay before recycling. The presence of a long lived radioisotope contaminant in the desired PET product can impact on its expiry time and use. Good target design is essential to ensure cost effectiveness and high quality product.

\subsection{Generator produced PET isotopes}

There is added complexity to the production and separation of short lived radioisotopes. For example, ${ }^{82} \mathrm{Rb}\left(\mathrm{T}_{1 / 2}=1.3 \mathrm{~min}\right),{ }^{68} \mathrm{Ga}\left(\mathrm{T}_{1 / 2}=67.6 \mathrm{~min}\right)$ and ${ }^{62} \mathrm{Cu}\left(\mathrm{T}_{1 / 2}=7.6 \mathrm{~min}\right)$ are all produced from their respective parent isotopes in a generator. These generators are then supplied to the PET facilities and milked periodically to resource the desired isotopes.

\subsection{Nuclear reactions for PET radioisotopes}

The type of nuclear reactions to produce a PET radioisotope can be quite varied. Table 4 summarises some of the more successful production routes for the PET radioisotopes, their nuclear reactions, useable energy range and the maximum cross section from the excitation function. The abundance of target element used for each reaction is also listed. 


\begin{tabular}{|c|c|c|c|c|c|}
\hline Nuclide & Nuclear Reaction & $\begin{array}{c}\text { Energy } \\
\text { Range } \\
{[\mathrm{MeV}]}\end{array}$ & $\begin{array}{c}\text { Natural } \\
\text { Abundance } \\
{[\%]}\end{array}$ & $\begin{array}{c}\text { Energy at } \\
\text { Maximum } \\
{[\mathrm{MeV}]}\end{array}$ & $\begin{array}{c}\text { Maximum } \\
\text { Cross-Section } \\
{[\mathrm{mb}]}\end{array}$ \\
\hline $44 \mathrm{mSc}$ & natTi $(p, x)^{44 m S c}$ & $28-48$ & Natural & 34 & 17 \\
\hline${ }^{48} \mathrm{~V}$ & ${ }^{48} \operatorname{Ti}(p, n)^{48 V}$ & $6-50$ & 73.8 & 12 & 380 \\
\hline $52 \mathrm{Mn}$ & natFe $(d, x)^{52} \mathrm{Mn}$ & $28-49$ & Natural & 38 & 166 \\
\hline $52 \mathrm{Fe}^{* *}$ & ${ }^{50} \mathrm{Cr}(\alpha, 2 \mathrm{n})^{52} \mathrm{Fe}$ & $20-42$ & 4.4 & 29,25 & 21,60 \\
\hline${ }^{52} \mathrm{Fe}$ & ${ }^{55} \mathrm{Mn}(\mathrm{p}, 4 \mathrm{n}){ }^{52} \mathrm{Fe}$ & $40-60$ & 100.0 & 54 & 100 \\
\hline${ }^{52} \mathrm{Fe}$ & ${ }^{52} \mathrm{Cr}\left({ }^{3} \mathrm{He}, 3 \mathrm{n}\right){ }^{52} \mathrm{Fe}$ & $25-40$ & 83.8 & 19 & 550 \\
\hline${ }^{55 \mathrm{Co}}$ & ${ }^{54} \mathrm{Fe}(\mathrm{d}, \mathrm{n}){ }^{55 \mathrm{Co}}$ & $5-10$ & 5.8 & 7 & 84 \\
\hline${ }^{55} \mathrm{Co}$ & ${ }^{56} \mathrm{Fe}(\mathrm{p}, 2 \mathrm{n})^{55 \mathrm{Co}}$ & $20-30$ & 91.7 & 25 & 70 \\
\hline${ }^{55} \mathrm{Co}$ & ${ }^{58 \mathrm{Ni}}(\mathrm{p}, \alpha)^{55 \mathrm{Co}}$ & $10-24$ & 68.3 & 17 & 40 \\
\hline $55 \mathrm{Co}$ & nat $\mathrm{Ni}(\mathrm{p}, \mathrm{x})^{55 \mathrm{Co}}$ & $11-22$ & Natural & 17 & 24 \\
\hline${ }^{55} \mathrm{Co}$ & natFe $(p, x)^{55} \mathrm{Co}$ & $16-42$ & Natural & 25 & 60 \\
\hline${ }^{55} \mathrm{Co}$ & ${ }^{55} \mathrm{Mn}\left({ }^{3} \mathrm{He}, 3 \mathrm{n}\right){ }^{55} \mathrm{Co}$ & $15-25$ & 100.0 & 19 & 550 \\
\hline${ }^{61} \mathrm{Cu}$ & ${ }^{61} \mathrm{Ni}(\mathrm{p}, \mathrm{n})^{61 \mathrm{Cu}}$ & $3-19$ & 1.1 & 10 & 480 \\
\hline${ }^{61} \mathrm{Cu}$ & nat $\mathrm{Ni}(\alpha, p)^{61} \mathrm{Cu}$ & $15-25$ & Natural & 27 & 450 \\
\hline${ }^{61} \mathrm{Cu}$ & ${ }^{59} \mathrm{Co}(\mathrm{a}, 2 \mathrm{n})^{61} \mathrm{Cu}$ & $18-60$ & 100.0 & 28 & 470 \\
\hline${ }^{61} \mathrm{Cu}$ & ${ }^{61} \mathrm{Ni}(\mathrm{p}, \mathrm{n}){ }^{61 \mathrm{Cu}}$ & $4-19$ & 1.1 & 10 & 500 \\
\hline $62 \mathrm{Zn}$ & ${ }^{\text {nat }} \mathrm{Cu}(\mathrm{p}, \mathrm{x})^{62 \mathrm{Zn}}$ & $14-61$ & Natural & 23 & 75 \\
\hline $62 \mathrm{Zn}$ & nat $\mathrm{Zn}(\mathrm{p}, \mathrm{x})^{62} \mathrm{Zn}$ & $28-70$ & Natural & 37 & 45 \\
\hline $63 \mathrm{Zn}$ & $\mathrm{nat}^{\mathrm{na}} \mathrm{u}(\mathrm{d}, \mathrm{x})^{63 \mathrm{Zn}}$ & $6-40$ & Natural & 17 & 420 \\
\hline $63 \mathrm{Zn}$ & nat $\mathrm{Cu}(\mathrm{p}, \mathrm{x})^{63 \mathrm{Zn}}$ & $6-50$ & Natural & 12 & 350 \\
\hline 63Zn & ${ }^{63} \mathrm{Cu}(\mathrm{p}, \mathrm{n}){ }^{63} \mathrm{Zn}$ & $4-40$ & 69.2 & 12 & 460 \\
\hline $63 \mathrm{Zn}$ & ${ }^{60} \mathrm{Ni}(\alpha \mathrm{n})^{63 \mathrm{Zn}}$ & $8-25$ & 26.1 & 19 & 550 \\
\hline${ }^{64} \mathrm{Cu}$ & ${ }^{61} \mathrm{Ni}(\alpha, p){ }^{64} \mathrm{Cu}$ & $5-15$ & 0.9 & 10 & 148 \\
\hline${ }^{64} \mathrm{Cu}$ & ${ }^{64} \mathrm{Ni}(\mathrm{p}, \mathrm{n})^{64} \mathrm{Cu}$ & $3-40$ & 0.9 & 11 & 700 \\
\hline${ }^{64} \mathrm{Cu}$ & ${ }^{64} \mathrm{Ni}(\mathrm{d}, 2 \mathrm{n}){ }^{64} \mathrm{Cu}$ & $5-50$ & 0.9 & 15 & 800 \\
\hline${ }^{64} \mathrm{Cu}$ & ${ }^{66} \mathrm{Zn}(\mathrm{d}, \alpha)^{64} \mathrm{Cu}$ & $8-14$ & 27.9 & 11 & 27 \\
\hline${ }^{64} \mathrm{Cu}$ & nat $\mathrm{Zn}(\mathrm{p}, \mathrm{x})^{64} \mathrm{Cu}$ & $\begin{array}{l}20-30 \\
30-65\end{array}$ & Natural & $\begin{array}{l}23 \\
40\end{array}$ & $\begin{array}{l}15 \\
25\end{array}$ \\
\hline${ }^{64} \mathrm{Cu}$ & ${ }^{68} \mathrm{Zn}(\mathrm{p}, \alpha \mathrm{n}){ }^{64} \mathrm{Cu}$ & $\begin{array}{l}16-45 \\
45-100\end{array}$ & 18.8 & $\begin{array}{l}25 \\
70\end{array}$ & $\begin{array}{l}75 \\
60\end{array}$ \\
\hline${ }^{66} \mathrm{Ga}$ & ${ }^{66} \mathrm{Zn}(\mathrm{p}, \mathrm{n})^{66} \mathrm{Ga}$ & $7-30$ & 27.8 & 12.5 & 650 \\
\hline $66 \mathrm{Ga}$ & natZn(p x $)^{66 \mathrm{Ga}}$ & $5-70$ & Natural & 15 & 150 \\
\hline${ }^{66} \mathrm{Ga}$ & ${ }^{63} \mathrm{Cu}(\alpha, n){ }^{66} \mathrm{Ga}$ & $10-26$ & 69.2 & 16 & 690 \\
\hline${ }^{68} \mathrm{Ga}$ & ${ }^{68} \mathrm{Zn}(\mathrm{p}, \mathrm{n})^{68} \mathrm{Ga}$ & $5-35$ & 18.8 & 11 & 830 \\
\hline${ }^{68} \mathrm{Ga}$ & ${ }^{65} \mathrm{Cu}(\alpha, \mathrm{n}){ }^{68} \mathrm{Ga}$ & $11-22$ & 30.83 & 17 & 850 \\
\hline${ }^{68} \mathrm{Ge}$ & nat $\mathrm{Zn}(\alpha, \mathrm{x})^{68} \mathrm{Ge}$ & $15-100$ & Natural & 30 & 155 \\
\hline${ }^{68} \mathrm{Ge}$ & ${ }^{66} \mathrm{Zn}(\alpha, 2 \mathrm{n})^{68} \mathrm{Ge}$ & $20-40$ & 27.8 & 30 & 550 \\
\hline${ }^{68} \mathrm{Ge}$ & $\left.{ }^{69} \mathrm{Ga}(p, 2 n)\right)^{68} \mathrm{Ge}$ & $13-36$ & 60.1 & 20 & 558 \\
\hline
\end{tabular}




\begin{tabular}{|c|c|c|c|c|c|}
\hline${ }^{68} \mathrm{Ge}$ & ${ }^{n a t} \mathrm{Ga}(\mathrm{p}, \mathrm{x})^{68} \mathrm{Ge}$ & $13-56$ & Natural & 21 & 325 \\
\hline${ }^{81} \mathrm{Rb}$ & ${ }^{81} \mathrm{Kr}(\mathrm{p}, \mathrm{x})^{81} \mathrm{Rb}$ & $\begin{array}{c}15-35 \\
35-100\end{array}$ & Natural & $\begin{array}{l}25 \\
50\end{array}$ & $\begin{array}{l}100 \\
190\end{array}$ \\
\hline${ }^{82} \mathrm{Rb}$ & ${ }^{85} \mathrm{Rb}(\mathrm{p}, 4 \mathrm{n}){ }^{82} \mathrm{Sr}$ & $38-100$ & 72.2 & 52 & 150 \\
\hline${ }^{82} \mathrm{Rb}$ & nat $R b(p, x)^{82} \mathrm{Sr}$ & $45-60$ & 72.2 & 52 & 100 \\
\hline${ }^{82} \mathrm{Rb}$ & ${ }^{82} \mathrm{Kr}(\alpha, 3 \mathrm{n}){ }^{83 \mathrm{Sr}}$ & $25-40$ & 11.6 & 30 & 280 \\
\hline $82 \mathrm{Sr}$ & ${ }^{82} \mathrm{Kr}\left({ }^{3} \mathrm{He}, 3 \mathrm{n}\right){ }^{82} \mathrm{Sr}$ & $19-35$ & 11.6 & 35 & 275 \\
\hline $86 Y$ & ${ }^{86} \mathrm{Sr}(\mathrm{p}, \mathrm{n})^{86 \mathrm{Y}}$ & $7-50$ & 9.9 & 13 & 950 \\
\hline $86 \mathrm{Y}$ & ${ }^{n a t} \operatorname{Zr}(\mathrm{d}, \mathrm{x})^{86} \mathrm{Y}$ & $31-50$ & Natural & 43 & 39 \\
\hline${ }^{86} \mathrm{Y}$ & ${ }^{86} \mathrm{Sr}(\mathrm{d}, 2 \mathrm{n}){ }^{86} \mathrm{Y}$ & $5-30$ & 9.9 & 19 & 691 \\
\hline $86 \mathrm{Y}$ & ${ }^{88} \mathrm{Sr}(\mathrm{p}, 3 \mathrm{n})^{86} \mathrm{Y}$ & $30-85$ & 82.6 & 40 & 470 \\
\hline $86 Y$ & ${ }^{85} \mathrm{Rb}(\alpha, 3 n)^{86} \mathrm{Y}$ & $29-50$ & 72.2 & 41 & 800 \\
\hline $89 \mathrm{Zr}$ & ${ }^{89} \mathrm{Y}(\mathrm{p}, \mathrm{n})^{89} \mathrm{Zr}$ & $5-50$ & 100.0 & 14 & 780 \\
\hline $89 \mathrm{Zr}^{* *}$ & ${ }^{89} \mathrm{Y}(\mathrm{d}, 2 \mathrm{n}){ }^{89} \mathrm{Zr}$ & $5-40$ & 100.0 & 16,20 & 700,1100 \\
\hline $94 \mathrm{mTc}$ & ${ }^{94} \mathrm{Mo}(\mathrm{p}, \mathrm{n}){ }^{94 \mathrm{mTc}}$ & $7-18$ & 9.3 & 12 & 460 \\
\hline
\end{tabular}

** Two references quoting different values.

Table 4. Common production routes of PET radioisotopes (Al-Abyad, M. et al., 2009; Aydin, A. et al., 2007; Brodzinski, R.L. et al., 1971; Fulmer, C.B. \& Williams, I.R., 1970; Hermanne, A. et al., 2000; Hille, M. et al., 1972; Ido, T. et al., 2002; International Atomic Energy Agency, 2009; Khandaker, M.U. et al., 2009; Sadeghi, M. et al., 2010; Sadeghi, M. et al., 2009;

Szelecsényi, F. et al., 2001; Szelecsenyi, F. et al., 2006; Takacs, S. et al., 2003; Takacs, S. et al., 2007; Tarkanyi, F. et al., 2005)

The cross sections for the production of ${ }^{68} \mathrm{Ga}$ via $\mathrm{p}$ and $\alpha$ bombardment of ${ }^{68} \mathrm{Zn}$ and ${ }^{65} \mathrm{Cu}$ targets respectively, are similar. The former production route would be preferred due to the wider availability of $\mathrm{p}$ producing cyclotrons. However it is important to note that ${ }^{66 \mathrm{Ga}}$ which has a longer half life, can be produced via $\mathrm{p}$ bombardment of ${ }^{66} \mathrm{Zn}$ in the same energy region. As the natural abundances for ${ }^{64} \mathrm{Zn}, 66 \mathrm{Zn}$ and $68 \mathrm{Zn}$ are $48.6 \%, 27.9 \%$ and $18.8 \%$, respectively, even small amounts of $64 \mathrm{Zn}$ and $66 \mathrm{Zn}$ present in enriched $(>95 \%) 68 \mathrm{Zn}$ will contribute to the production of contaminating isotopes.

Generators for the production of ${ }^{82} \mathrm{Rb}\left(\mathrm{T}_{1 / 2}=1.3 \mathrm{~min}\right)$ and ${ }^{68} \mathrm{Ga}\left(\mathrm{T}_{1 / 2}=67.6 \mathrm{~min}\right)$ are commercially available. The long half lives of their respective parents, ${ }^{82} \mathrm{Sr}\left(\mathrm{T}_{1 / 2}=25.3\right.$ days $)$ and ${ }^{68} \mathrm{Ge}\left(\mathrm{T}_{1 / 2}=270.8\right.$ days $)$ means the generators have a life-time of months to almost a year. However the challenge in the production of these generators is that they must stand up to repeated milking over at least twice the lifetime of the generator to demonstrate that there is no breakdown of the column material or any leaching of contaminating long lived radioisotopes. The parent of ${ }^{62} \mathrm{Cu},{ }^{62} \mathrm{Zn}$ has a short half-life and needs to be prepared daily.

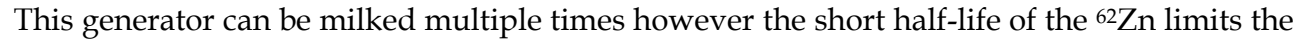
lifetime of its use to less than a day.

A comparison of the maximum cross section and the energy range suitable for the production of each PET isotope on a $30 \mathrm{MeV}$ cyclotron is illustrated in Figure 11. The green and blue icons represent $\mathrm{p}$ and $\mathrm{d}$ reactions at the maximum cross section. The associated error bar reflects the useable energy ranges (cross section $>10 \mathrm{mb}$ ) for the respective reactions. 


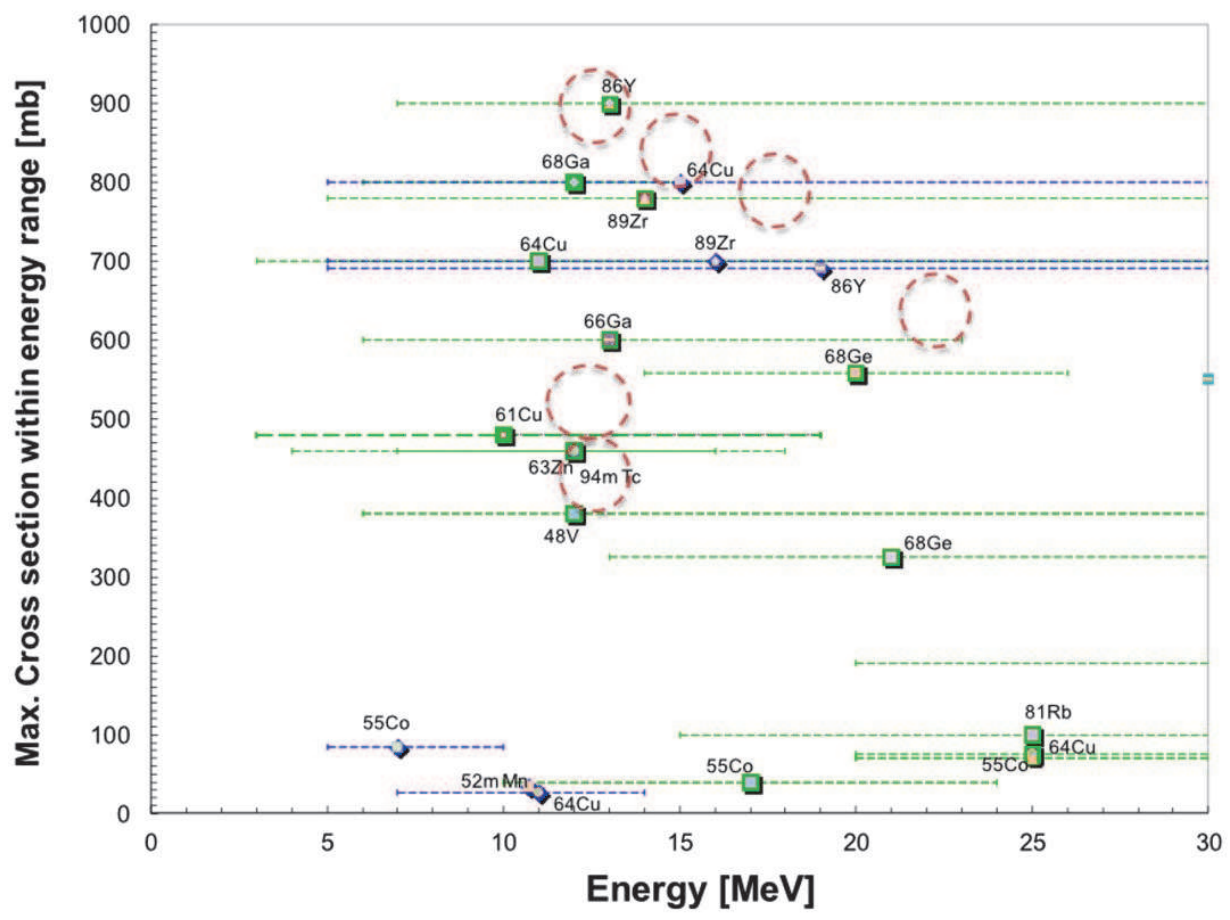

Fig. 11. Radioisotopes produced using protons and deuteron in the energy range 0-30 MeV.

In general, the production of radioisotopes via proton bombardment are more common across the energy ranges, as their high cross sections provide for higher yields. In contrast, nuclear reactions with deuterons are less common. This is not surprising as maintaining a stable beam of these particles at a high current is more difficult.

Reactions for ${ }^{86} \mathrm{Y},{ }^{68} \mathrm{Ga},{ }^{64} \mathrm{Cu},{ }^{89} \mathrm{Zr},{ }^{66} \mathrm{Ga},{ }^{68} \mathrm{Ge},{ }^{61} \mathrm{Cu},{ }^{63} \mathrm{Zn},{ }^{94 m \mathrm{Tc}}$ and ${ }^{48} \mathrm{~V}$ in Figure 11 have a very high probability. However the cost effectiveness of their production relies on the enrichment of their target material. The targets used to produce ${ }^{89} \mathrm{Zr},{ }^{48} \mathrm{~V},{ }^{63} \mathrm{Zn},{ }^{68} \mathrm{Ga}$ and ${ }^{68} \mathrm{Ge}$ are of high $(>60 \%)$ natural abundance (identified by the orange circles in Figure 11) and therefore will yield high quantities of these radioisotopes at comparatively reasonable cost. Once the preferred reaction route is identified then a separation method for the radioisotope needs to be developed. The separation methods need to be robust, reliable and cost effective in order to maintain a routine supply of the desired radioisotope.

\section{Conclusions}

Designing a PET radiopharmaceutical relies on careful consideration of a number of factors. They include the physical characteristics of the radioisotope, its chemistry and half life. For the former the critical aspects are the positron and gamma energies. A radioisotope with a low maximum positron energy is always preferred. The presence of any gammas contribute to radiation dose. High energy gammas require additional lead shielding and this significantly increases the cost of infrastructure. Gammas in the 350-700 keV range decrease PET image resolution and will require longer imaging times. The application of the 
radiopharmaceuticals in PET imaging will depend on the radioisotope's chemistry and biological half-life. The former requires the separation and radiolabelling to take place rapidly without extensive infrastructure and technical skills. Advances in the ability of cyclotrons to produce $\mathrm{p}, \mathrm{d}$ and $\alpha$ particles have substantially increased the range of metal PET radioisotopes that can be produced. However the yield and the cost effectiveness of the radioisotope production are ultimately dependent on the choice of nuclear reaction and the natural abundance of the target material used. Metal PET radioisotopes are ideal for labelling small molecules, peptides, proteins and particles via chelators and clearly have a role in the diagnosis of disease and risk assessment of new drugs. Of the 21 metal PET radioisotopes evaluated, ${ }^{61} \mathrm{Cu}$ and ${ }^{64} \mathrm{Cu}$ best meet the criteria for human use.

\section{References}

Al-Abyad, M., Comsan, M.N.H. \& Qaim, S.M. (2009). Excitation functions of proton-induced reactions on Fe-nat and enriched Fe-57 with particular reference to the production of Co-57. Applied Radiation and Isotopes, Vol. 67, 1, (Jan, 2009), pp. (122-128), 09698043

Aydin, A., Sarer, B. \& Tel, E. (2007). New calculation of excitation functions of protoninduced reactions in some medical isotopes of $\mathrm{Cu}, \mathrm{Zn}$ and $\mathrm{Ga}$. Applied Radiation and Isotopes, Vol. 65, 3, (2007), pp. (365-370), 0969-8043

Baker, M. (2010). The whole picture. Nature, Vol. 463, 7283, (2010), pp. (977-980), 0028-0836

Bockisch, A., Freudenberg, L.S., Schmidt, D. \& Kuwert, T. (2009). Hybrid imaging by SPECT/CT and PET/CT: Proven outcomes in cancer imaging. Seminars in Nuclear Medicine, Vol. 39, 4, (Jul, 2009), pp. (276-289), 0001-2998

Brodzinski, R.L., Rancitelli, L.A., Cooper, J.A. \& Wogman, N.A. (1971). High-energy proton spallation of titanium. Physical Review C, Vol. 4, 4, (October, 1971), pp. (1250-1257),

Cai, W.B. \& Chen, X.Y. (2008). Multimodality molecular imaging of tumor angiogenesis. Journal of Nuclear Medicine, Vol. 49, Suppl. 2, (June, 2008), pp. (113S-128S), 01615505

Cañadas, M.E., M. Lage, E. Desco, M. Vaquero, J.J. Pérez, J.M. (2008). Nema nu 4-2008 performance measurements of two commercial small-animal PET scanners: Clear PET RPET-1 Nuclear Science, IEEE Transactions on Vol. 58, 1 2008), pp. (4773-4779), 0018-9499

Cropley, V.L., Fujita, M., Innis, R.B. \& Nathan, P.J. (2006). Molecular imaging of the dopaminergic system and its association with human cognitive function. Biological Psychiatry, Vol. 59, 10, (May, 2006), pp. (898-907), 0006-3223

Frost \& Sullivan (2010). Emerging technology developments in hybrid imaging. Frost and Sullivan Technical Insights Reports.

Fulmer, C.B. \& Williams, I.R. (1970). Excitation functions for radioactive nucleides produced by deuteron-induced reactions in copper. Nuclear Physics Vol. A155, (June, 1970), pp. (40-48),

Gabriel, M., Decristoforo, C., Kendler, D., Dobrozemsky, G., Heute, D., Uprimny, C., Kovacs, P., Von Guggenberg, E., Bale, R. \& Virgolini, I.J. (2007). Ga-68-dota-tyr(3)octreotide PET in neuroendocrine tumors: Comparison with somatostatin receptor scintigraphy and ct. Journal of Nuclear Medicine, Vol. 48, 4, (Apr, 2007), pp. (508-518), 0161-5505 
Gomes, C.M.F., Abrunhosa, A.J. \& Pauwels, E.K.J. (2011). Molecular imaging with SPECT and PET in exploratory investigational new drug studies. Drugs of the Future, Vol. 36, 1, (Jan, 2011), pp. (69-77), 0377-8282

Gregoire, V., Haustermans, K., Geets, X., Roels, S. \& Lonneux, M. (2007). PET-based treatment planning in radiotherapy: A new standard? Journal of Nuclear Medicine, Vol. 48, (Jan, 2007), pp. (68S-77S), 0161-5505

Haddad, F., Ferrer, L., Guertin, A., Carlier, T., Michel, N., Barbet, J. \& Chatal, J.F. (2008). Arronax, a high-energy and high-intensity cyclotron for nuclear medicine. European Journal of Nuclear Medicine and Molecular Imaging, Vol. 35, 7, (Jul, 2008), pp. (13771387), 1619-7070

Henze, M., Schuhmacher, J., Hipp, P., Kowalski, J., Becker, D.W., Doll, J., Macke, H.R., Hofmann, M., Debus, J. \& Haberkorn, U. (2001). PET imaging of somatostatin receptors using (68)Ga dota-d-phe(1)-tyr(3)-octreotide: First results in patients with meningiomas. Journal of Nuclear Medicine, Vol. 42, 7, (Jul, 2001), pp. (1053-1056), 0161-5505

Hermanne, A., Sonck, M., Takacs, S. \& Tarkanyi, F. (2000). Experimental study of excitation functions for some reactions induced by deuterons (10-50 MeV on natural Fe and Ti. Nuclear Instruments $\mathcal{E}$ Methods in Physics Research Section B-Beam Interactions with Materials and Atoms, Vol. 161, (Mar, 2000), pp. (178-185), 0168-583X

Hille, M., Hille, P., Uhl, M. \& Weisz, W. (1972). Excitation functions of (p, n) and (a ,n) reactions on Ni, Cu and Zn. Nuclear Physics, Vol. A198, (1972), pp. (625-640),

Holland, J.P., Williamson, M.J. \& Lewis, J.S. (2010) Unconventional nuclides for radiopharmaceuticals. Molecular Imaging, Vol. 9, 1, (Jan-Feb 2010), pp. (1-20), 15353508 http://www.nndc.bnl.gov/. Retrieved 21 May 2011.

Hubbell, J.H. (1969). Photon cross sections, attenuation coefficients, and energy absorption coefficients from $10 \mathrm{keV}$ to $100 \mathrm{GeV}$ National Standard Reference Data System.

Ido, T., Hermanne, A., Ditroi, F., Szucs, Z., Mahunka, I. \& Tarkanyi, F. (2002). Excitation functions of proton induced nuclear reactions on Rb-nat from 30 to $70 \mathrm{MeV}$. Implication for the production of Sr-82 and other medically important $\mathrm{rb}$ and $\mathrm{sr}$ radioisotopes. Nuclear Instruments $\mathcal{E}$ Methods in Physics Research Section B-Beam Interactions with Materials and Atoms, Vol. 194, 4, (Oct, 2002), pp. (369-388), 0168$583 X$

International Atomic Energy Agency (2006). Directory of cyclotrons used for radionuclide production in member states-2006 update. Vienna, Austria.

International Atomic Energy Agency (2009). Cyclotron produced radionuclides : Physical characteristics and production methods. Technical reports series No 468. Vienna, Austria.

Khandaker, M.U., Kim, K., Lee, M.W., Kim, K.S., Kim, G.N., Cho, Y.S. \& Lee, Y.O. (2009). Investigations of the Ti-nat(p,x)Sc-43,Sc-44m,Sc-44g,Sc-46,Sc-47,Sc-48,V-48 nuclear processes up to $40 \mathrm{MeV}$. Applied Radiation and Isotopes, Vol. 67, 7-8, (Jul-Aug, 2009), pp. (1348-1354), 0969-8043

Kitajima, K., Murakami, K., Sakamoto, S., Kaji, Y. \& Sugimura, K. (2011). Present and future of FDG-PET/CT in ovarian cancer. Annals of Nuclear Medicine, Vol. 25, 3, (Apr, 2011), pp. (155-164), 0914-7187 
Laforest, R. \& Liu, X. (2008). Image quality with non-standard nuclides in PET. Quarterly Journal of Nuclear Medicine and Molecular Imaging, Vol. 52, 2, (Jun, 2008), pp. (151158), 1824-4661

Lancelot, S. \& Zimmer, L. (2010) Small-animal positron emission tomography as a tool for neuropharmacology. Trends in Pharmacological Sciences, Vol. 31, 9, (Sep 2010), pp. (411-417), 0165-6147

Langer, A. (2010) A systematic review of PET and PET/CT in oncology: A way to personalize cancer treatment in a cost-effective manner? MC Health Services Research, Vol. 10, (Oct), pp. (16), 1472-6963

Le Loirec, C. \& Champion, C. (2007a). Track structure simulation for positron emitters of medical interest. Part I: The case of the allowed decay isotopes. Nuclear Instruments $\mathcal{E}$ Methods in Physics Research Section A-Accelerators Spectrometers Detectors and Associated Equipment, Vol. 582, 2, (Nov, 2007a), pp. (644-653), 0168-9002

Le Loirec, C. \& Champion, C. (2007b). Track structure simulation for positron emitters of physical interest. Part II: The case of the radiometals. Nuclear Instruments $\mathcal{E}$ Methods in Physics Research Section A-Accelerators Spectrometers Detectors and Associated Equipment, Vol. 582, 2, (Nov, 2007b), pp. (654-664), 0168-9002

Lee, J.S. (2010). Technical advances in current PET and hybrid imaging systems. The Open Nuclear Medicine Journal, Vol. 2,(2010), pp. (192-208),

Lewellen, T.K. (2008). Recent developments in PET detector technology. Physics in Medicine and Biology, Vol. 53, 17, (Sep, 2008), pp. (R287-R317), 0031-9155

Li, Z.B., Chen, K. \& Chen, X. (2008). Ga-68-labeled multimeric RGD peptides for microPET imaging of integrin alpha(v)beta(3) expression. European Journal of Nuclear Medicine and Molecular Imaging, Vol. 35, 6, (Jun, 2008), pp. (1100-1108), 1619-7070

Liu, Z.F., Yan, Y.J., Liu, S.L., Wang, F. \& Chen, X.Y. (2009). F-18, Cu-64, and Ga-68 labeled rgd-bombesin heterodimeric peptides for PET imaging of breast cancer. Bioconjugate Chemistry, Vol. 20, 5, (May, 2009), pp. (1016-1025), 1043-1802

Lonsdale, M.N. \& Beyer, T. (2010)Dual-modality PET/CT instrumentation -today and tomorrow. European Journal of Radiology, Vol. 73, 3, (Mar 2010), pp. (452-460), 0720048X

Madsen, M.T., Anderson, J.A., Halama, J.R., Kleck, J., Simpkin, D.J., Votaw, J.R., Wendt, R.E., Williams, L.E. \& Yester, M.V. (2006). Aapm task group 108: PET and PET/CT shielding requirements. Medical Physics, Vol. 33, 1, (Jan, 2006), pp. (4-15), 0094-2405

Moses, W.W. (2007). Recent advances and future advances in time-of-flight PET. Nuclear Instruments $\mathcal{E}$ Methods in Physics Research Section A-Accelerators Spectrometers Detectors and Associated Equipment, Vol. 580, 2, (Oct, 2007), pp. (919-924), 0168-9002

Moses, W.W., Virador, P.R.G., Derenzo, S.E., Huesman, R.H. \& Budinger, T.F. (1997). Design of a high-resolution, high-sensitivity PET camera for human brains and small animals. IEEE Transactions on Nuclear Science, Vol. 44, 4, (Aug, 1997), pp. (14871491), 0018-9499

Partridge, M., Spinelli, A., Ryder, W. \& Hindorf, C. (2006). The effect of positron energy on performance of a small animal PET camera. Nuclear Instruments and Methods in Physics Research A, Vol. 568, (2006), pp. (933-936),

Petrusenko, Y.T., Lymar, A.G., Nikolaichuk, L.I., Tutubalin, A.I., Shepelev, A.G., Ponomarenko, T.A. \& Nemashkalo, O.V. (2009). Analysis of data arrays on 
cyclotron production of medical radioisotopes. Problems of Atomic Science and Technology, Vol., 3,( 2009), pp. (82-88), 1562-6016

Pimlott, S.L. \& Sutherland, A.(2011) Molecular tracers for the pet and spect imaging of disease. Chemical Society Reviews, Vol. 40, 1), pp. (149-162), 0306-0012

Roach, M., Alberini, J.L., Pecking, A.P., Testori, A., Verrecchia, F., Soteldo, J., Ganswindt, U., Joyal, J.L., Babich, J.W., Witte, R.S., Unger, E. \& Gottlieb, R. (2011). Diagnostic and therapeutic imaging for cancer: Therapeutic considerations and future directions. Journal of Surgical Oncology, Vol. 103, 6, (May, 2011), pp. (587-601), 0022-4790

Ruangma, A., Bai, B., Lewis, J.S., Sun, X.K., Welch, M.J., Leahy, R. \& Laforest, R. (2006). Three-dimensional maximum a posteriori (map) imaging with radiopharmaceuticals labeled with three $\mathrm{Cu}$ radionuclides. Nuclear Medicine and Biology, Vol. 33, 2, (2006), pp. (217-226), 0969-8051

Sadeghi, M., Enferadi, M., Aref, M. \& Jafari, H. (2010). Nuclear data for the cyclotron production of Ga-66, Y-86, Br-76, Cu-64 and Sc-43 in PET imaging. Nukleonika, Vol. 55, 3, 2010), pp. (293-302), 0029-5922

Sadeghi, M., Zali, A. \& Mokhtari, L. (2009). Calculations of Y-86 production via various nuclear reactions. Nuclear Science and Techniques, Vol. 20, 6, (Dec, 2009), pp. (369372), 1001-8042

Sanchez-Crespo, A., Andreo, P. \& Larsson, S.A. (2004). Positron flight in human tissues and its influence on pet image spatial resolution. European Journal of Nuclear Medicine and Molecular Imaging, Vol. 31, 1,(2004), pp. (44-51), 1619-7070

Schmor, P.W. (2010). Review of cyclotrons used in the production of radioisotopes for biomedical applications, Proceedings of Cyclotrons 2010, Lanzhou, China, September, 2010

Seam, P., Juweid, M.E. \& Cheson, B.D. (2007). The role of FDG-PET scans in patients with lymphoma. Blood, Vol. 110, 10, (Nov, 2007), pp. (3507-3516), 0006-4971

Senthamizhchelvan, S., Bravo, P.E., Lodge, M.A., Merrill, J., Bengel, F.M. \& Sgouros, G. (2011). Radiation dosimetry of Rb-82 in humans under pharmacologic stress. Journal of Nuclear Medicine, Vol. 52, 3, (Mar, 2011), pp. (485-491), 0161-5505

Smith, S. V. (2004). Molecular imaging with copper-64. J. Inorg. Biochem., Vol. 98, 11, (2004), pp. (1874-1901), 0162-0134.

Smith, S.V. (2005). Challenges and opportunities for positron-emission tomography in personalized medicine. Idrugs, Vol. 8, 10, (Oct, 2005), pp. (827-833), 1369-7056

Smith, S.V. (2007). Molecular imaging with copper-64 in the drug discovery and development arena. Expert Opinion on Drug Discovery, Vol. 2, 5, (May, 2007), pp. (659-672), 1746-0441

Szelecsényi, F., Kovács, Z., Suzuki, K., Takei, M. \& Okada, K. (2001). Investigation of direct production of ${ }^{62} \mathrm{cu}$ radioisotope at low energy multiparticle accelerator for PET studies, Proceedings of International Symposium on Utilization of Accelerators, Sao Paulo, Brazil, November, 2001

Szelecsenyi, F., Steyn, G.F., Kovacs, Z., van der Walt, T.N. \& Suzuki, K. (2006). Comments on the feasibilty of $\mathrm{Cu}-61$ production by proton irradiation of (nat $\mathrm{Zn}$ ) on a medical cyclotron. Applied Radiation and Isotopes, Vol. 64, 7, (Jul, 2006), pp. (789-791), 09698043

Takacs, S., Tarkanyi, F., Hermanne, A. \& de Corcuera, R.P. (2003). Validation and upgrading of the recommended cross section data of charged particle reactions used for 
production of pet radioisotopes. Nuclear Instruments $\mathcal{E}$ Methods in Physics Research Section B-Beam Interactions with Materials and Atoms, Vol. 211, 2, (Oct, 2003), pp. (169189), 0168-583X

Takacs, S., Tarkanyi, F., Kiraly, B., Hermanne, A. \& Sonck, M. (2007). Evaluated activation cross sections of longer-lived radionuclides produced by deuteron induced reactions on natural nickel. Nuclear Instruments $\mathcal{E}$ Methods in Physics Research Section B-Beam Interactions with Materials and Atoms, Vol. 260, 2, (Jul, 2007), pp. (495-507), 0168-583X

Tarkanyi, F., Ditroi, F., Csikai, J., Takacs, S., Uddin, M.S., Hagiwara, M., Baba, M., Shubin, Y.N. \& Dityuk, A.I. (2005). Activation cross-sections of long-lived products of proton-induced nuclear reactions on zinc. Applied Radiation and Isotopes, Vol. 62, 1, (Jan, 2005), pp. (73-81), 0969-8043

Truong, M.T., Viswanathan, C. \& Erasmus, J.J. (2011). Positron emission tomography/computed tomography in lung cancer staging, prognosis, and assessment of therapeutic response. Journal of Thoracic Imaging, Vol. 26, 2, (May, 2011), pp. (132-146), 0883-5993

Vandenberghe, S. (2006). Three-dimensional positron emission tomography imaging with I124 and Y-86. Nuclear Medicine Communications, Vol. 27, 3, (Mar, 2006), pp. (237245), 0143-3636

Vyas, N.S., Patel, N.H., Nijran, K.S., Al-Nahhas, A. \& Puri, B.K. (2011). The use of pet imaging in studying cognition, genetics and pharmacotherapeutic interventions in schizophrenia. Expert Review of Neurotherapeutics, Vol. 11, 1, (Jan, 2011), pp. (37-51), 1473-7175

Wahl, R.L., Jacene, H., Kasamon, Y. \& Lodge, M.A. (2009). From recist to percist: Evolving considerations for PET response criteria in solid tumors. Journal of Nuclear Medicine, Vol. 50, (May, 2009), pp. (122S-150S), 0161-5505

Wang, C., Li, H.D., Ramirez, R.A., Zhang, Y.X., Baghaei, H., Liu, S.T., An, S.H. \& Wong, W.H.(2010) A real time coincidence system for high count-rate TOF or non-TOF PET cameras using hybrid method combining and-logic and time-mark technology. IEEE Transactions on Nuclear Science, Vol. 57, 2, (Apr-2010), pp. (708-714), 0018-9499

Winant, C.D., Kim, S. \& Seo, Y.(2010) Functional imaging combined with multi-detector CT: A radionuclide imaging perspective. Current Medical Imaging Reviews, Vol. 6, 2, (May), pp. (100-111), 1573-4056

Wolf, W. (2011). The unique potential for noninvasive imaging in modernizing drug development and in transforming therapeutics: PET/MRI/MRS. Pharmaceutical Research, Vol. 28, 3, (Mar, 2011), pp. (490-493), 0724-8741 


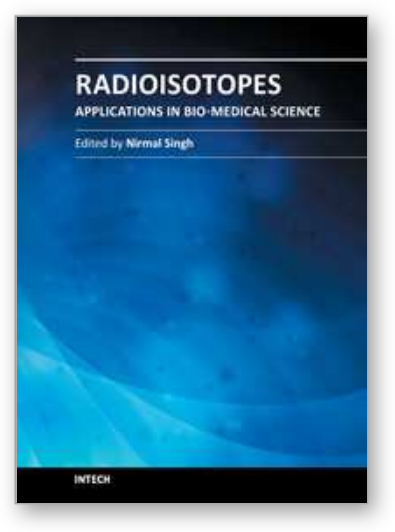

\author{
Radioisotopes - Applications in Bio-Medical Science \\ Edited by Prof. Nirmal Singh
}

ISBN 978-953-307-748-2

Hard cover, 320 pages

Publisher InTech

Published online 21, November, 2011

Published in print edition November, 2011

The book Radioisotopes - Applications in Bio-Medical Science contains two sections: Radioisotopes and Radiations in Bioscience and Radioisotopes and Radiology in Medical Science. Section I includes chapters on medical radioisotope production, radio-labeled nano-particles, radioisotopes and nano-medicine, use of radiations in insects, drug research, medical radioisotopes and use of radioisotopes in interdisciplinary fields etc. In Section II, chapters related to production of metal PET (positron emission tomography) radioisotopes, 3-dimensional and CT (computed tomography) scan, SS nuclear medicine in imaging, cancer diagnose and treatments have been included. The subject matter will by highly useful to the medical and paramedical staff in hospitals, as well as researchers and scholars in the field of nuclear medicine medical physics and nuclear biochemistry etc.

\title{
How to reference
}

In order to correctly reference this scholarly work, feel free to copy and paste the following:

Suzanne V. Smith, Marian Jones and Vanessa Holmes (2011). Production and Selection of Metal PET Radioisotopes for Molecular Imaging, Radioisotopes - Applications in Bio-Medical Science, Prof. Nirmal Singh (Ed.), ISBN: 978-953-307-748-2, InTech, Available from: http://www.intechopen.com/books/radioisotopesapplications-in-bio-medical-science/production-and-selection-of-metal-pet-radioisotopes-for-molecular-imaging

\section{INTECH}

open science | open minds

\author{
InTech Europe \\ University Campus STeP Ri \\ Slavka Krautzeka 83/A \\ 51000 Rijeka, Croatia \\ Phone: +385 (51) 770447 \\ Fax: +385 (51) 686166 \\ www.intechopen.com
}

\author{
InTech China \\ Unit 405, Office Block, Hotel Equatorial Shanghai \\ No.65, Yan An Road (West), Shanghai, 200040, China \\ 中国上海市延安西路65号上海国际贵都大饭店办公楼 405 单元 \\ Phone: +86-21-62489820 \\ Fax: +86-21-62489821
}


(C) 2011 The Author(s). Licensee IntechOpen. This is an open access article distributed under the terms of the Creative Commons Attribution 3.0 License, which permits unrestricted use, distribution, and reproduction in any medium, provided the original work is properly cited. 